\title{
Assessing the key photophysical properties of triangulenium dyes for DNA binding by alteration of the fluorescent core
}

Benjamin W. Lewis ${ }^{\# 1,2}$ Niels Bisballe ${ }^{\#}{ }^{3}$ Marco Santella, ${ }^{3}$ Peter A. Summers, ${ }^{1}$ Jean-Baptiste Vannier, ${ }^{4,5}$ Marina K. Kuimova*, ${ }^{1,2}$ Bo W. Laursen*, ${ }^{3}$ Ramon Vilar*1,2

\# these authors contributed equally to this work

*corresponding authors:

m.kuimova@imperial.ac.uk, bwl@chem.ku.dk, r.vilar@imperial.ac.uk

${ }^{1}$ Department of Chemistry, Molecular Sciences Research Hub, White City Campus, Imperial College London, W12 OBZ, UK.

${ }^{2}$ Institute of Chemical Biology, White City Campus, Imperial College London, W12 OBZ, UK.

${ }^{3}$ Department of Chemistry \& Nano-Science Center, University of Copenhagen, Universitetsparken 5, 2100 Copenhagen, Denmark.

${ }^{4}$ Telomere Replication and Stability group, Medical Research Council - London Institute of Medical Sciences, London, W12 0NN, UK.

${ }^{5}$ Institute of Clinical Sciences, Faculty of Medicine, Imperial College London, London, W12 ONN, UK. 


\section{Table of Contents Graphical Abstract}

This paper reports on two new optical probes for DNA based on diazatriangulenium dyes featuring ethyl-morpholino substituents. Upon interaction with duplex and quadruplex DNA, these two probes switch on their fluorescence intensity and change their emission lifetime (although the latter is not dependent on the DNA topology). This has allowed us to study the cellular uptake and localisation of the two new probes in cancer cells. Whilst structural modifications to the diazatriangulenium core only slightly alter the binding affinity to DNA, their cellular localisation is significantly altered.
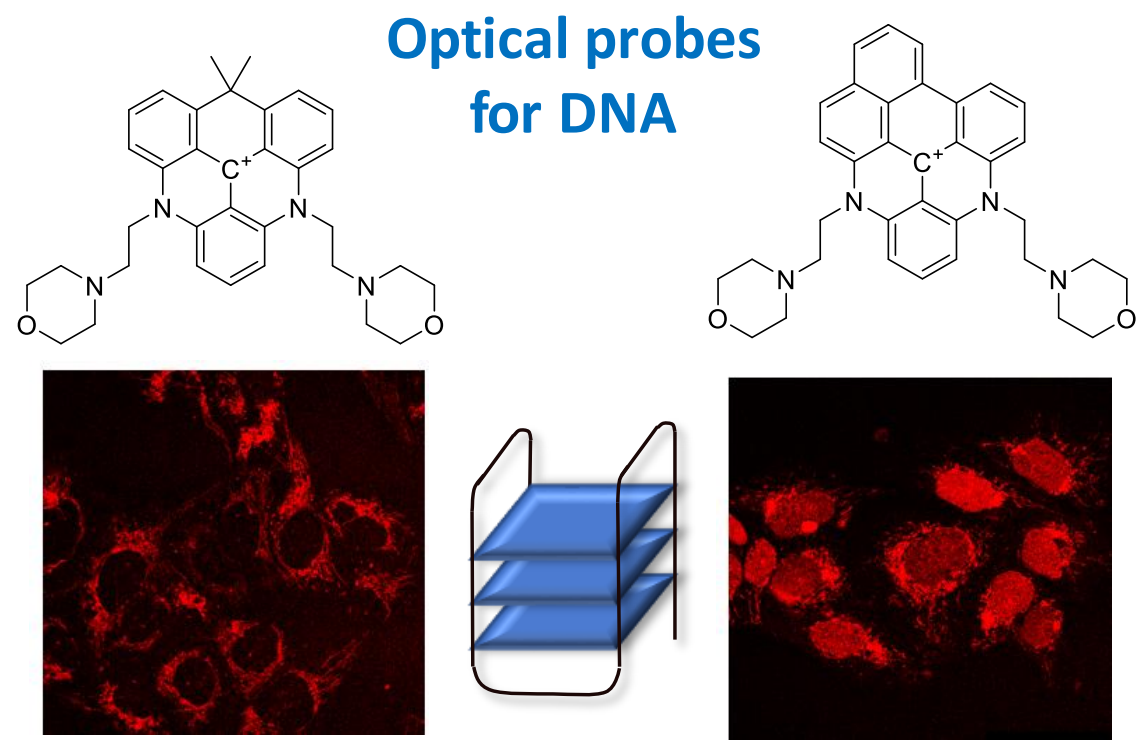

Keywords: DNA, G-quadruplex, Optical probes, Trianguleniums, Cellular Imaging 


\section{Abstract}

Four-stranded G-quadruplex (G4) DNA is a non-canonical DNA topology that has been proposed to form in cells and play key roles in how the genome is read and used by the cellular machinery. Previously, a fluorescent triangulenium probe (DAOTA-M2) was used to visualise G4s in cellulo, thanks to its distinct fluorescence lifetimes when bound to different DNA topologies. Herein, we expand the library of available triangulenium probes to explore how modifications to the fluorescent core of the molecule affect its photophysical characteristics, interaction with DNA and cellular localisation. The benzo-bridged and isopropyl-bridged diazatriangulenium dyes, BDATA-M2 and CDATA-M2 respectively, featuring ethylmorpholino substituents, were synthesised and characterised. The interactions of these molecules with different DNA topologies were studied to determine their binding affinity, fluorescence enhancement and fluorescence lifetime response. Finally, the cellular uptake and localisation of these optical probes were investigated. Whilst structural modifications to the triangulenium core only slightly alter the binding affinity to DNA, BDATA-M2 and CDATAM2 cannot distinguish between DNA topologies through their fluorescence lifetime. We argue theoretically and experimentally that this is due to reduced effectiveness of photoinduced electron transfer (PET) quenching. This work presents valuable new evidence into the critical role of PET quenching when using the fluorescence lifetime of triangulenium dyes to discriminate G4 DNA from duplex DNA, highlighting the importance of fine tuning redox and spectral properties when developing new triangulenium-based G4 probes. 


\section{Introduction}

Although the base sequence of DNA holds the genetic information, how this information is used is increasingly recognised to be regulated by the DNA secondary structure. Whilst strands of DNA can adopt a wide range of different structures under various conditions, only those which are stable under physiological conditions are relevant to cell function. One of these non-canonical secondary structures are the four-stranded G-quadruplexes (G4).

G4s are stable in guanine rich sequences of $D N A^{[1]}$ and form because of the ability of guanine bases to interact with one another through Hoogsteen hydrogen bonding interactions. Four guanine bases can form a G-tetrad structure in this manner, stabilised by a central monovalent metal cation - most commonly potassium. When two or more of these G-tetrads stack on top of each other via $\pi-\pi$ interactions, the tetra-stranded helical structure of G4s emerges $^{[2]}$. Significant work has been carried out to fully characterise the properties of these G-quartets ${ }^{[3]}$.

Critically, G4 DNA is stable under physiological conditions, leading to speculation that this DNA topology may exist in cellulo and play a role in a wide range of biological processes ${ }^{[4-7]}$. A range of computational, biophysical and imaging methods have been applied to characterise G4 DNA and its biological implications ${ }^{[8,9]}$. Computational studies estimated there are over 400,000 putative $G 4$ forming sequences present in the human genome $e^{[10,11]}$, whilst studies using genetic sequencing suggested there could be as many as $700,000^{[12]}$. More recent measurements have observed around 10,000 G4s enriched from human chromatin $^{[13]}$. Evidence has been found suggesting that G4 DNA is involved in a wide range of biological processes, including cell replication ${ }^{[14,15]}$, regulation of gene expression ${ }^{[13,16-19]}$ and 
telomere maintenance ${ }^{[20-23]}$ - as well as a wide range of disease states ${ }^{[24]}$. There have been many attempts to use G4 DNA as a target for cancer therapy ${ }^{[25-28]}$.

Much of our understanding of G4 DNA in a biological context comes from studies using G4binding antibodies such as $B G 4^{[29]}$, but this method requires cell membrane permeabilisation via cell fixation, hence live cells cannot be studied. The effects of fixation and the use of nanomolar affinity binders which themselves could template $\mathrm{G} 4$ formation, may result in a picture not entirely reflective of the native nuclear context. The ultimate goal is to develop a method for studying G4 DNA directly in living cells, so that dynamic processes can be observed directly in the native biological setting.

Fluorescence imaging with exogenous fluorophores is a widely used technique for visualizing cell content by selectively targeting the structure of interest. Many fluorescence probes that light up in the presence of G4 DNA, but not duplex DNA, have been developed ${ }^{[30]}$. However, the fluorescence switch-on factor scales with concentration of both the probe and the DNA topology and since G4 DNA makes up only a small fraction of the total DNA inside a cell nucleus, a G4 specific small molecule binder based on fluorescence intensity is challenging to develop. Single molecule fluorescence detection can provide a sensitive means to detect individual G4 binding events in real-time following the fluorescence intensity of the probe ${ }^{[31]}$. An alternative strategy is to use fluorescence lifetime of a probe to image G4 DNA. The fluorescence lifetime of a dye is determined by its local environment and is concentration independent, potentially allowing the observation of a low concentration species such as G4 DNA, even in the presence of large excess of duplex DNA ${ }^{[32,33]}$.

Previously, we have reported DAOTA-M2 [Figure 1], a triangulenium dye, which has been successfully used as a G4 DNA probe on the basis of fluorescence lifetime ${ }^{[32,34,35]}$. DAOTA-M2 
can bind to G4 DNA by stacking onto the end faces of the quadruplex structure ${ }^{[35]}$, and also binds to double stranded (ds) DNA. In either case, the binding is facilitated by the $\pi-\pi$ interaction of the molecule's aromatic core with DNA bases and electrostatic interactions between the cationic dye and the negatively charged DNA. DAOTA-M2 shows a fluorescence turn-on effect on interaction with DNA and binds with similar affinity to G4 and non-G4 DNA structures. Interestingly, upon binding to G4 DNA, DAOTA-M2 displays a longer fluorescence lifetime than when bound to other DNA topologies. Additionally, DAOTA-M2 is cell permeable and localises primarily in the cell nucleus, which make it an appealing optical probe for live cell imaging. Indeed, fluorescence lifetime imaging microscopy (FLIM) with DAOTA-M2 has shown lifetimes in the nucleus which change when the cells are treated with strong G4 DNA binders (e.g. pyridostatin $)^{[32]}$. These observations are indicative of the presence of cellular G4 DNA topologies.

Although DAOTA-M2 has already demonstrated its use as an optical probe to study G4 DNA, some of its properties, such as its brightness, could be improved. The triangulenium core structure easily lends itself to synthetic modifications ${ }^{[36-40]}$. Therefore, we set out to explore whether alternative triangulenium cores may have attractive properties as G4s probes such as greater discrimination of lifetimes for G4 over other topologies, increased brightness, or different binding selectivity. 
<smiles>c1cc2oc3cccc4c3[c+]3c2c(c1)n(CCN1CCOCC1)c1cccc(c13)n4CCN1CCOCC1</smiles>

DAOTA-M2

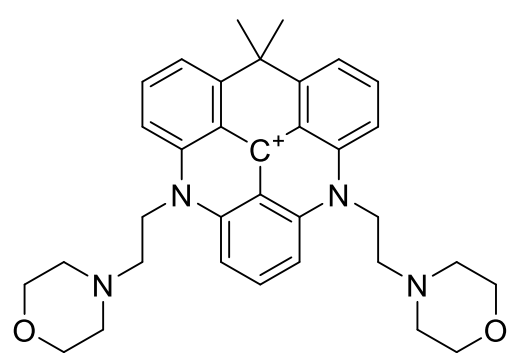

CDATA-M2

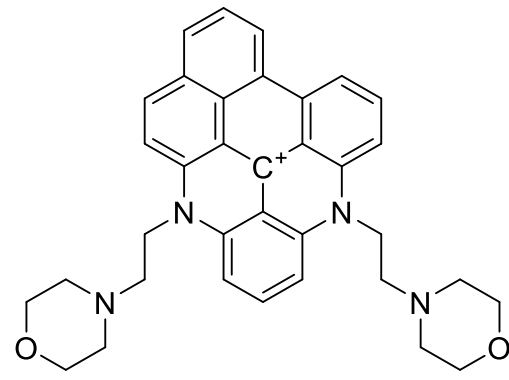

BDATA-M2

Figure 1. Structures of DAOTA-M2, CDATA-M2 and BDATA-M2.

Herein, we present two new analogues of the DAOTA-M2 probe based on modification of the fluorescent triangulenium core of the molecule. In each of these derivatives the oxygen bridge has been replaced. BDATA-M2 instead has an additional fused benzene ring lending additional aromatic character. The rationale to select this extended $\pi$-system was to make the probe more hydrophobic compared to DAOTA-M2, thus increasing $\pi-\pi$ stacking interactions with DNA. CDATA-M2 instead has a bridging dimethyl group which reduces the overall aromatic character of the core and introduces steric bulk out of the plane of the aromatic system. This deviation from planarity could help the probe to preferentially bind to G4 DNA rather than intercalate in dsDNA. Both the $\mathrm{CDATA}^{+}$and $\mathrm{BDATA}^{+}$fluorophores have the advantage of being redshifted relative to $\mathrm{DAOTA}^{+}$, which is advantageous for bioimaging ${ }^{[37,38]}$. We present the photophysical, thermodynamic and biophysical characterisation of these molecules and investigate how these variations in the fluorophore's properties impact its interactions with G4 and duplex DNA. We also show that changes in the triangulenium core have an impact on the cellular localisation of the corresponding optical probes. 


\section{Results and discussion}

\section{Synthesis of CDATA-M2 and BDATA-M2}

CDATA-M2 was synthesised from the previously reported triangulenium dye, CDOTA ${ }^{+}$ (Scheme 1$)^{[37]}$. First, we attempted to access CDATA-M2 in a single step from reacting CDOTA ${ }^{+}$ with 2-morpholinoethylamine, but the yield of this reaction was very low $(<1 \%)$. Instead we first introduced a simpler, more stable side chain and subsequently added the morpholino group via an $\mathrm{S}_{\mathrm{N}} 2$ reaction. Reacting $\mathrm{CDOTA}^{+}$with ethanolamine gave the corresponding $\mathrm{CDATA}^{+}$derivative with a primary alcohol on the side chain (1). The alcohol was converted to a good leaving group for the subsequent substitution by tosylation (2). We found that tosylation with the sulfonyl chloride resulted in low yields and gave rise to chlorinated products leading to challenging purifications. Using the sulfonic anhydride in its place provided a route that gave better purity and yields. CDATA-M2 was finally obtained by refluxing $\mathbf{2}$ with morpholine in acetonitrile. 
<smiles>CC1(C)Oc2cccc3oc4cccc1c4[c+](-c1ccccc1)c23</smiles>

CDOTA $^{+}$
$\mathrm{PF}_{6}{ }^{-}$<smiles>NCCO</smiles><smiles>O=C(O)P</smiles>

NMP, $120^{\circ} \mathrm{C}$

$72 \mathrm{~h}$

$59 \%$<smiles>CC1(C)c2cccc3c2[c+](-c2ccccc2)c2c1cccc2n3CCO</smiles>

1

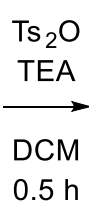

$38 \%$<smiles>CC1(C)c2cccc3c2[C+]2c4cccc(c4-3)N(CCO[AsH2-])c3cccc(c32)N1CC[Se-]</smiles>

2

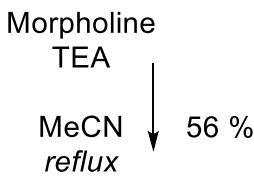

$72 \mathrm{~h}$

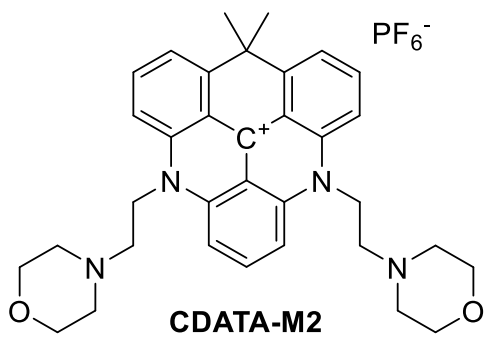

Scheme 1. Synthetic pathway for CDATA-M2 via tosylation. NMP = N-Methyl-2-pyrrolidone, Ts = paratoluenesulfonyl, TEA = triethylamine, DCM = dichloromethane.

A similar approach (Scheme 2) was used to synthesise BDATA-M2, starting from the reported benzo[a]xanthenium precursor (3) of the previously described BDATA $^{+}$chromophore ${ }^{[38]}$. Heating with ethanolamine in NMP formed the cationic diaza[5]helicene (4). Upon treatment with $p$-toluenesulfonic anhydride the primary alcohols were tosylated (5). As per the synthesis of $\mathbf{2}$, we avoided using tosyl chloride to prevent the formation of chlorinated impurities. The morpholino groups could then be introduced by refluxing 5 in acetonitrile with morpholine to give $\mathbf{6}$. For the final ring-closing reaction, $\mathbf{6}$ was heated in polyphosphoric acid to give BDATAM2 in low yields, but enough pure material was obtained for the purpose of this study. Detailed synthetic procedures and product characterisation are given in Supporting Information. 
<smiles>COc1cccc(OC)c1-[c+]1c2c(OC)cccc2oc2ccc3ccccc3c21</smiles>

3

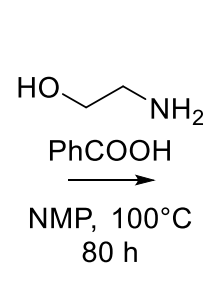

$22 \%$

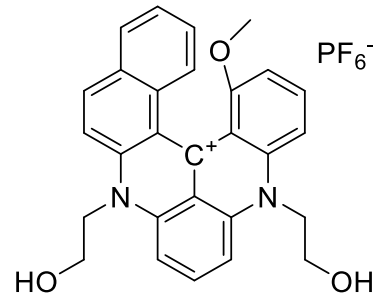

4

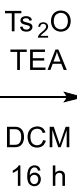

$44 \%$

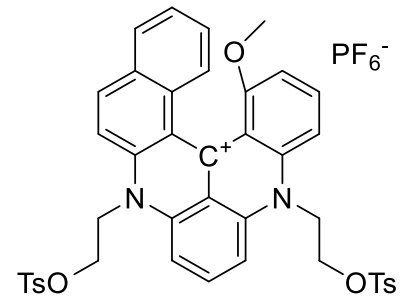

5<smiles>COc1cccc2c1[C@@H]1c3c(cccc3N(CCN3CCOCC3)c3cccc(C(F)(F)C(F)(F)F)c31)N2CCN1CCOCC1</smiles>

Scheme 2. Synthetic pathway for BDATA-M2 via tosylation. NMP = N-Methyl-2-pyrrolidone, Ts = paratoluenesulfonyl, TEA = triethylamine, $\mathrm{DCM}=$ dichloromethane, $\mathrm{PPA}=$ polyphosphoric acid.

\section{Photophysical characterisation of BDATA-M2 and CDATA-M2}

The absorption and fluorescence spectra of CDATA-M2 and BDATA-M2 are significantly red shifted compared to DAOTA-M2 [Figure 2(a) and (b)]. In aqueous lithium cacodylate buffer at physiological $\mathrm{pH}(7.3)$ this shift amounts to 47 and $70 \mathrm{~nm}$ for CDATA-M2 and BDATA-M2 respectively ( $c f$. to the $\lambda_{\max }=552 \mathrm{~nm}$ for DAOTA-M2). Similarly, the emission maximum red shift is 47 and $92 \mathrm{~nm}$ for CDATA-M2 and BDATA-M2, respectively (cf. $\lambda_{\mathrm{em}}=579 \mathrm{~nm}$ for DAOTA-M2). Consequently, CDATA-M2 features a smaller Stokes shift of $720 \mathrm{~cm}^{-1}(27 \mathrm{~nm})$ than DAOTA-M2 (845 $\left.\mathrm{cm}^{-1}, 27 \mathrm{~nm}\right)$ while BDATA-M2 features a larger Stokes shift of 1174 $\mathrm{cm}^{-1}(49 \mathrm{~nm})$. 
a

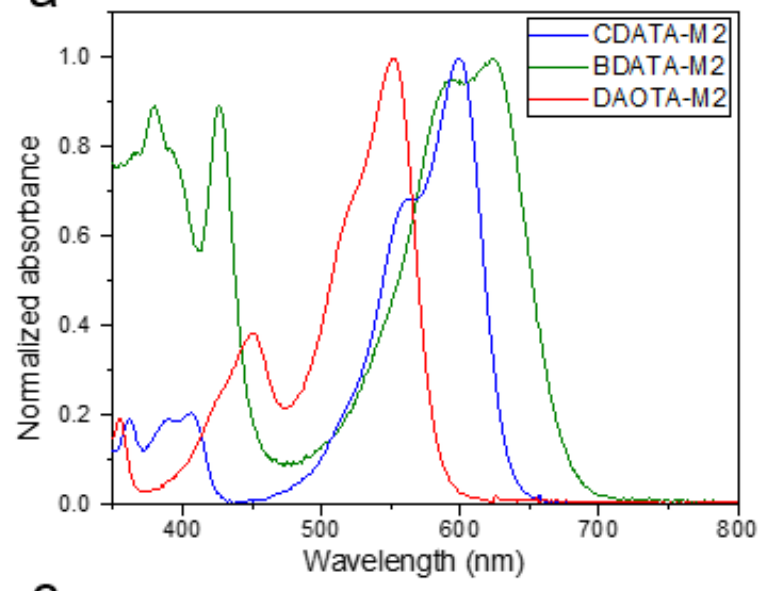

C

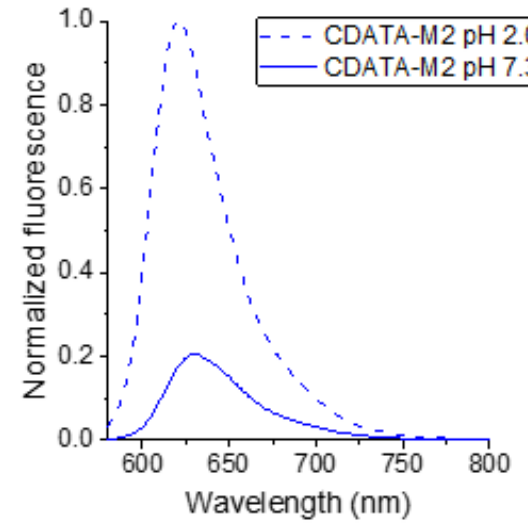

b
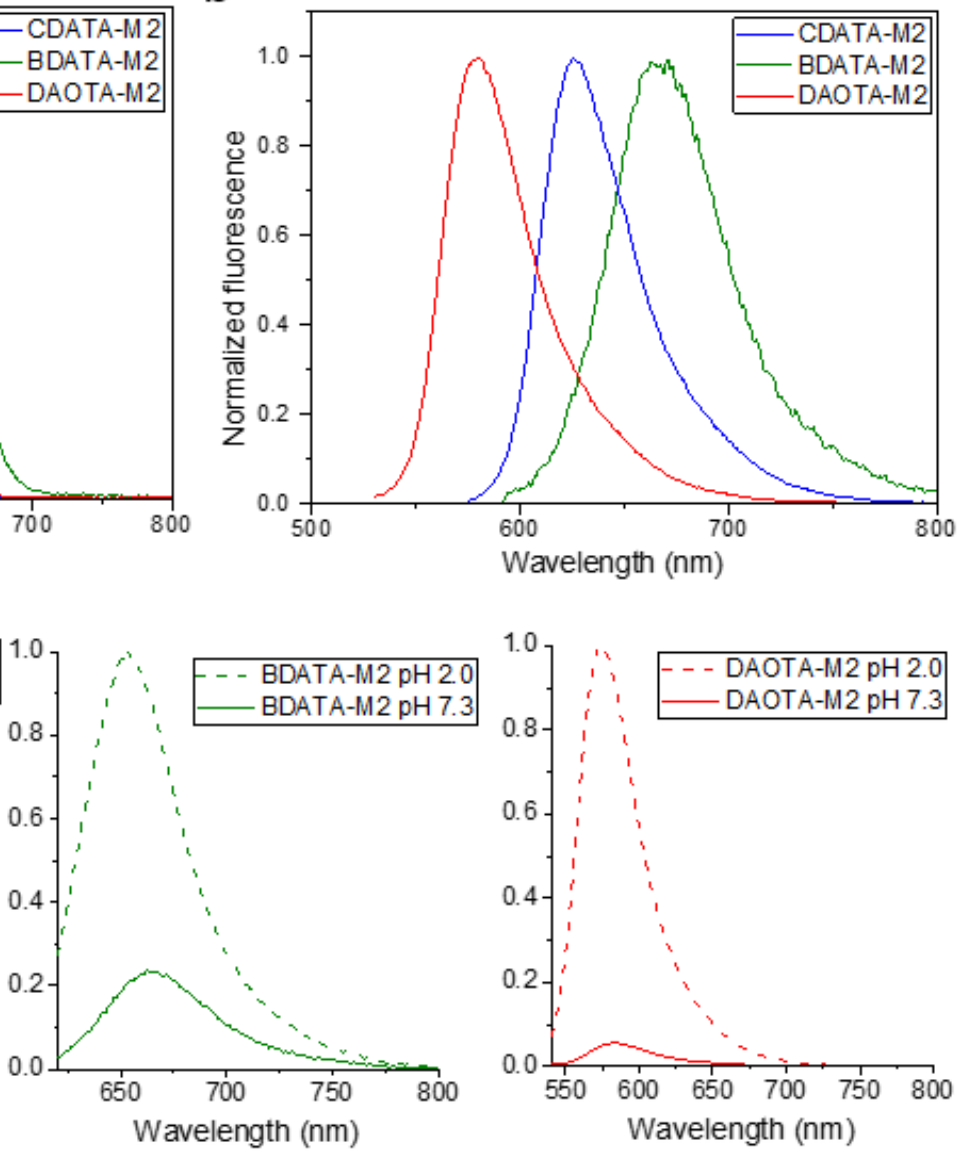

Figure 2. (a) Normalized absorbance spectra for DAOTA-M2, CDATA-M2 and BDATA-M2. (b) Normalized fluorescence emission spectra for DAOTA-M2, CDATA-M2 and BDATA-M2. (c) Fluorescence emission spectra of DAOTA-M2, CDATA-M2 and BDATA-M2 at pH 7.3 relative to $\mathrm{pH} 2.0$, fluorescence at $\mathrm{pH} 2.0$ was normalised for each respective dye. All spectra recorded in $10 \mathrm{mM}$ lithium cacodylate buffer.

An important property of triangulenium dyes containing morpholino groups is the ability for their fluorescence to be quenched by the morpholino groups in a $\mathrm{pH}$ dependent manner. DAOTA-M2 displays a 13.5-fold fluorescence enhancement when going from $\mathrm{pH} 7.3$ to $\mathrm{pH} 2.0$ in lithium cacodylate buffer, due to a reduction in quenching upon the protonation of the morpholino groups ${ }^{[32]}$. Interestingly, the enhancement was significantly lower for both CDATA-M2 and BDATA-M2, 4.4-fold and 3.4-fold at $\mathrm{pH} 2.0$, respectively [Figure 2(c)]. The enhancement of fluorescence upon acidification shows that, at physiological $\mathrm{pH}$, both CDATA- 
M2 and BDATA-M2 exist in their deprotonated forms, which is expected considering that the pKa of the morpholino groups in DAOTA-M2 is found to be as low as $4.5^{[32]}$.

Another observation made for BDATA-M2 was a difference in the shape of the absorption spectrum at physiological and acidic pH [Figure S3], most notably the relative size of the shoulder at $595 \mathrm{~nm}$. Similar spectral changes have previously been reported for the formation of $\mathrm{H}$-aggregates of organic dyes in water ${ }^{[41-44]}$. The planar, lipophilic structure of the BDATA ${ }^{+}$ chromophore led us to investigate its tendency to aggregate in aqueous solution. To avoid interference from the morpholino groups, we first looked at the spectra of the previously reported parent chromophore BDATA-Me ${ }^{[38]}$ in water with increasing DMSO concentration [Figure S2]. A similar change in the absorption spectra was seen as for the change of the BDATA-M2 spectrum with changing $\mathrm{pH}$, as well as a large increase in fluorescence intensity upon addition of DMSO. Notably, the fluorescence enhancement from disaggregation is comparable to the $\mathrm{pH}$-dependent enhancement of BDATA-M2.

To relate these findings back to the BDATA-M2 probe, its concentration dependent aggregation in aqueous solution was investigated [Figure S1], showing the same change of shape in the absorption spectra as BDATA-Me2. Emission intensities were also found to deviate from the linear trend expected from a freely solvated dye. Based on these findings we attribute the changes in the absorption spectra to the formation of dye aggregates in aqueous solution. 


\section{Thermodynamics of the observed quenching behaviour}

In order to better understand the observed fluorescence enhancements, we studied the parameters governing the quenching of the excited state probes by the morpholino groups. As previously demonstrated for DAOTA-M2, the mechanism responsible is reductive photoinduced electron transfer $(\mathrm{PET})^{[34]}$. This process can only occur when a free electron pair is present on the morpholine nitrogen and its protonation at acidic $\mathrm{pH}$ will thus prevent PET based quenching. The Gibb's free energy of PET $\left(\Delta G^{0}{ }_{E T}\right)$ in the cationic triangulenium system can be estimated using Equation $1^{[45,46]}$ :

$$
\Delta G_{E T}^{0}=E^{0}\left(D^{+\bullet} / D\right)-E^{0}\left(A^{+} / A^{\bullet}\right)-\Delta E_{0,0} \quad(\text { Eq } 1)
$$

where $E^{0}\left(D^{+\bullet} / D\right)$ is the standard electrode potential of the electron donating morpholino cation radical, $E^{0}\left(\mathrm{~A}^{+} / \mathrm{A}^{\circ}\right)$ is the standard electrode potential of the electron accepting triangulenium cation and $\Delta E_{0,0}$ is the energy of the first excited state of the triangulenium dye derived from the optical spectra. The results of the calculation, using the measured optical spectra and electrochemical parameters for each of the three probes are summarised in Table 1. 
Table 1. Results of calculating the free energy gain from PET for the three morpholino substituted probes with Eq 1.

\begin{tabular}{|c|c|c|c|}
\hline & CDATA-M2 & BDATA-M2 & DAOTA-M2 \\
\hline$E^{0}\left(\mathrm{D}^{+\bullet} / \mathrm{D}\right)[\mathrm{V}]^{a}$ & 1.34 & 1.34 & 1.34 \\
\hline$E^{0}\left(A^{+} / A^{0}\right)[V]^{b}$ & -0.63 & -0.63 & -0.72 \\
\hline$\Delta E_{0,0}[\mathrm{eV}]^{c}$ & 2.02 & 1.92 & 2.19 \\
\hline$\Delta_{\mathrm{ET}} G_{0}[\mathrm{eV}]$ & -0.05 & 0.05 & -0.13 \\
\hline Fl. enhancement ${ }^{d}$ & 4.4 & 3.4 & 13.5 \\
\hline
\end{tabular}

These results indicate that PET is favourable for DAOTA-M2 and CDATA-M2, but not for BDATA-M2. While DAOTA-M2 is harder to reduce than the other probes and therefore less likely to undergo reduction, this is offset by a more energetic electronic transition. CDATAM2 and BDATA-M2 are easier to reduce, but their electronic transitions are of lower energy, making PET less favourable as a result. As is predicted by Marcus Theory for electron transfer, a greater gain in free energy for the electron transfer reaction $\left(\Delta \mathrm{G}^{0} \mathrm{ET}\right)$ leads to faster PET and thus to more efficient quenching. This explains why DAOTA-M2 fluorescence is quenched more efficiently than CDATA-M2 and BDATA-M2 at physiological pH (with the morpholino groups being deprotonated). From the positive value of $\Delta \mathrm{G}^{0} \mathrm{ET}$ calculated for BDATA-M2, PET would not be expected. Still, an enhancement in fluorescence is observed when acidifying the aqueous medium. We explain this observation by the breakup of aggregates at $\mathrm{pH} 2$ [Figure S3], aided by improved aqueous solvation of the protonated side chains. However, given the assumptions and approximations in the estimation of $\Delta \mathrm{G}^{0} \mathrm{ET}$, we cannot entirely rule out a 
minor PET contribution to the observed effect. These results provide new, deeper thermodynamic insight into the observed photophysical behaviour of these dyes.

\section{Interaction of BDATA-M2 and CDATA-M2 with DNA oligonucleotides}

DAOTA-M2, interacts with DNA through $\pi-\pi$ interactions, stacking the aromatic core of the triangulenium molecule onto either end of G4 $\mathrm{DNA}^{[35]}$ or binding to dsDNA, possibly through intercalation. Its binding affinities to G4 DNA and dsDNA are similar ( $\log \mathrm{Ka}=5.7-6.1$, Figure S68), and both result in a fluorescence turn-on (slightly greater for G4), however, the fluorescence lifetimes observed upon binding are significantly different, which allows various DNA topologies to be distinguished ${ }^{[32]}$. Here, we set out to explore the effect of DNA binding on the fluorescence signatures of BDATA-M2 and CDATA-M2.

Both BDATA-M2 and CDATA-M2 display similar fluorescence characteristics to DAOTA-M2 on binding DNA, with their fluorescence intensity enhanced on binding to any DNA topology. Fluorescence emission titrations were carried out to determine the binding affinity of each new probe for different G4 DNA (c-myc, HRAS1 and ckit87up) and dsDNA (ds17 and CT-DNA) topologies [Figure 3, Figures S5-14, Table S1] and compare these values with those previously determined for DAOTA-M2. Absorption titrations were also carried out, to establish the binding stoichiometry of the triangulenium probes for each DNA topology [Figures S15-24]. In addition, whilst emission titrations are more accurate for determining binding affinity, this was also determined by fitting the absorption titrations to check for agreement with the emission titrations [Figures S66-67, Table S4]. For both DAOTA-M2 and CDATA-M2, binding to DNA is associated with a drop in the probe's absorbance, whereas a sharp increase was observed for BDATA-M2. 
The binding affinities determined for both probes via emission titrations are shown in Figure 3a. CDATA-M2 has similar binding affinity to G4 DNA (log Ka 5.4-6.6) and a lower binding affinity for dsDNA (log Ka 4.6-5.1) than DAOTA-M2. These results can be rationalised through differences in the CDATA-M2 structure, which has out-of-plane alkyl groups on the fluorescent core, disrupting the planar aromatic surface which drives the binding. Whilst this may not have an impact on end-stacking to G4 DNA where there are fewer steric constrains for these alkyl groups, this added steric hindrance is likely to make intercalation between base pairs or groove binding to dsDNA less favourable.

The binding affinities of BDATA-M2 for G4 DNA (log Ka 5.0-6.6) are broadly in line with those of DAOTA-M2, with a slightly higher affinity for non-G4 DNA (log Ka 6.6-6.9). This is not unexpected since the addition of another ring to the planar aromatic core of BDATA-M2 gives greater surface for $\pi-\pi$ interactions. 

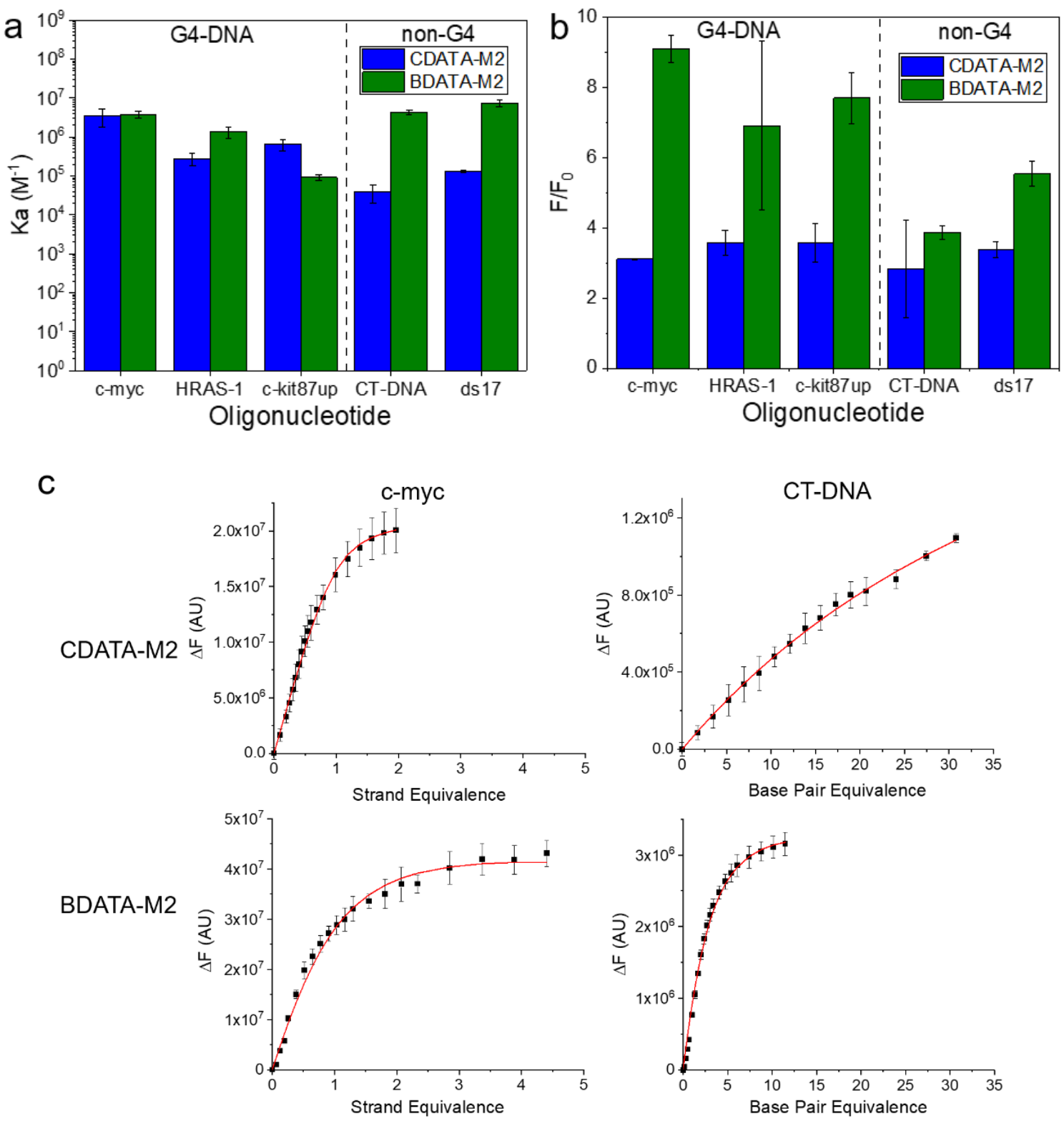

Figure 3. (a) Determined binding affinity constants of CDATA-M2 and BDATA-M2 for a range of G4 and non-G4 DNA oligonucleotides. Values determined by independent fitting of three fluorescence emission titrations. Error bar is standard deviation of affinity determined from repeat measurements. Comparable data for DAOTA-M2 published previously ${ }^{[32]}$ is found in Figure S68. (b) Fluorescence turnon effect for CDATA-M2 and BDATA-M2 bound to a range of $\mathrm{G} 4$ and non-G4 oligonucleotides. Values calculated from the average enhancement observed in three fluorescence emission titrations, with the final fluorescence determined from the plateau of the fitted function used to calculate the binding constant. Error bar is standard deviation from three titrations. (c) Fluorescence titration curves for CDATA-M2 and BDATA-M2 fluorescence emission with added c-myc G4 oligonucleotide and CT-DNA conducted in $10 \mathrm{mM}$ lithium cacodylate buffer containing $100 \mathrm{mM}$ potassium chloride. Error bars show standard deviation of three repeat measurements. Red line shows fit calculated for the average of the three independent titrations. 
As previously reported, nucleobases can quench the fluorescence of triangulenium derivatives by intermolecular PET, via Guanine oxidation ${ }^{[34]}$. However, for di-aza-substituted trianguleniums (such as those presented here), this effect is energetically less favourable with the local environment around the fluorescent core playing a more important role. We have previously shown that for DAOTA-M2 the morpholino substituents give rise to intramolecular PET quenching, which supersedes intermolecular nucleobase PET quenching ${ }^{[34]}$. Given DAOTA-M2 in its excited state is easier to reduce compared to the other two probes (due to a more energetic electronic transition), the intermolecular PET from CDATA-M2 and BDATAM2 is even less likely to occur. Binding to DNA constrains the movement of the morpholino substituents reducing the quenching rate. This is more pronounced in G4 DNA compared to other DNA topologies, which is reflected in characteristic fluorescence lifetime values upon binding to various DNA topologies.

From the emission titrations, the fluorescence turn-on effect can also be quantified [Figure 3(b)]. For DAOTA-M2, enhancement when binding to G4 DNA was higher (3.3-4.9x) than binding to dsDNA (2.0-2.8x). This enhancement is still short of the highest potential turn-on predicted by the $\mathrm{pH}$ studies, suggesting that PET quenching is still competing with fluorescence, even when bound to $\mathrm{G} 4$ (and, to a greater extent, when bound to dsDNA). CDATA-M2 demonstrates a similar level of enhancement in fluorescence intensity to that shown by DAOTA-M2. In the presence of G4 DNA, fluorescence enhancement is 3.1-3.6x, whilst in the presence of other DNA topologies it is 2.8-3.4x. Unlike for DAOTA-M2, however, the degree of turn-on when bound to G4 DNA is in line with the fluorescence response expected from almost complete alleviation of PET quenching found in the $\mathrm{pH}$ dependent emission study discussed in the previous section [Figure 2]. 
In contrast, BDATA-M2 has a greater fluorescence enhancement on binding to DNA (both G4 and dsDNA), compared to CDATA-M2 and DAOTA-M2. For G4 DNA, the enhancement is 6.99.1x, whilst enhancement with dsDNA is $3.8-5.6 x$. The similar enhancement seen with all topologies point at the absence of any significant difference in alleviation of PET quenching. Rather, enhancement is likely due to DNA-mediated disaggregation of BDATA-M2, which, as discussed above, is aggregated in aqueous solution. This is supported by comparison of the absorption spectra observed during titration of BDATA-M2 with DNA and the studies of aggregation using DMSO [Figure S4]. This is also consistent with the calculated Gibb's free energy of PET, rendering the conformational differences in binding irrelevant for BDATA-M2. Notably, binding to either DNA topology results in a greater fluorescence turn-on than full protonation of the quenching groups. A likely explanation is the increase in sample absorbance also associated with disaggregation - not only do the fluorophores emit more light upon excitation, but also, they are excited more efficiently.

\section{Fluorescence Lifetime response of BDATA-M2 and CDATA-M2 to DNA binding}

The key characteristic of DAOTA-M2 exploited to discriminate G4 DNA from other topologies is its fluorescence lifetime, which is higher upon binding G4 DNA compared to other DNA topologies. Thus, we set out to explore the fluorescence lifetime behaviour of BDATA-M2 and CDATA-M2 upon binding to a range of nucleic acid topologies. Time-correlated single photon counting (TCSPC) was used to measure the fluorescence lifetime of each molecule in the presence of an excess of G4 DNA or non-G4 DNA topologies, ensuring a minimum signal from unbound dye. Time resolved fluorescence decays were fit with biexponential decay functions 
(as was previously done for DAOTA-M2 ${ }^{[32]}$ ), to find a characteristic fluorescence lifetime value on binding to each topology.
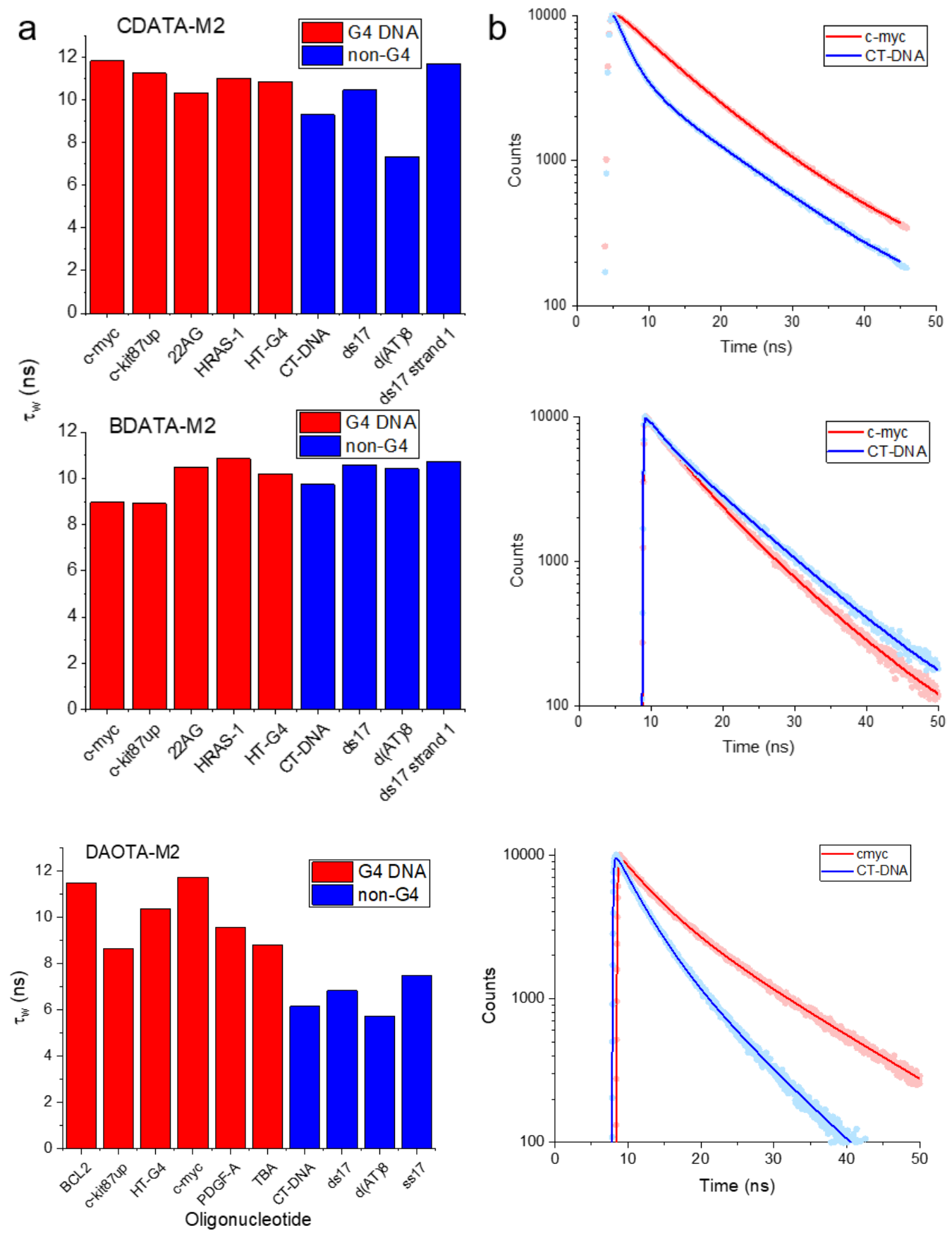

Figure 4. (a) Intensity-weighted average fluorescence lifetime for BDATA-M2 and CDATA-M2 bound to a range of G4 and non-G4 DNA oligonucleotides. (b) Representative time-resolved fluorescence decays for BDATA-M2 and CDATA-M2 bound to a G4 DNA oligonucleotide (c-myc) or a non-G4 DNA oligonucleotide (CT-DNA). Data points show the measured decays and lines show the fitted decay function describing each measurement. Decays with peak maximum $>10000$ counts were scaled down for comparison. (c) Intensity-weighted average fluorescence lifetime and time-resolved fluorescence decays for DAOTA-M2 bound to G4 and non-G4 DNA oligonucleotides, for comparison. 
These data show that there was no clear discrimination of DNA based on topology using either BDATA-M2 or CDATA-M2 [Figure 4, Figures S25-42, Tables S2-3]. There was significant overlap in the intensity-weighted average lifetimes observed on binding G4 DNA and on binding the non-G4 topologies studied. In the case of BDATA-M2, the lifetimes on binding to dsDNA and ssDNA were in some cases longer than those observed upon binding to G4 DNA. For CDATA-M2, although G4 oligonucleotides often demonstrated longer fluorescence lifetime, this was not consistent enough to accurately discriminate G4 from non-G4. This contrasts with DAOTA-M2, which consistently displays longer fluorescence lifetimes upon binding to G4 DNA.

The observed fluorescence lifetime for BDATA-M2 bound to DNA (up to approx. $11 \mathrm{~ns}$ ) is similar to that of the chromophore without morpholino groups, BDATA-Me2, in DCM (12.2 $n s)^{[38]}$ and underlines the favourable hydrophobic environment that DNA provides for organic fluorophores and absence of a significant effect of PET in this system. In terms of fluorescence lifetime, CDATA-M2 is also close to its dimethyl substituted parent chromophore in DCM (15.8 $\left.\mathrm{ns}^{[37]}\right)$, but the increased difference compared to BDATA-M2 shows there is some influence of PET quenching. DAOTA-M2 is significantly quenched by PET even upon G4 DNA binding (intensity-weighted average lifetime up to $12 \mathrm{~ns}$ ), with lifetimes significantly shorter than that seen at acidic $\mathrm{pH}(18.3 \mathrm{~ns})^{[32]}$.

Taken together, the fluorescence lifetime observed for both BDATA-M2 and CDATA-M2 bound to DNA shows that neither can clearly discriminate G4 DNA from other DNA topologies, unlike DAOTA-M2. We suggest this difference is due to the intrinsically weaker PET quenching of BDATA-M2 and CDATA-M2. We therefore conclude that PET quenching is, indeed, a key 
element in the successful discrimination of DNA topologies by DAOTA-M2 and can be significantly altered by even small changes to the fluorescent core.

\section{Cellular experiments using BDATA-M2 and CDATA-M2}

In order to determine the effect of changing the triangulenium core on cytotoxicity, cellular uptake and localisation, osteosarcoma U2OS cells were incubated with BDATA-M2 and CDATA-M2. Cell viability was determined using an MTS assay [Figure S60] and, similarly to DAOTA-M2 ${ }^{[32]}$, the IC50 values were determined to be at concentrations above those routinely used for imaging ( $>40 \mu \mathrm{M}$ for both dyes).

To study uptake and localisation, U2OS cells stained with either triangulenium dye were costained with the nuclear dye Hoechst 33342, lysosomal dye LysoTracker Green or mitochondrial dye MitoTracker Orange to examine the cellular localisation of the dyes. The image analysis reveals that BDATA-M2 appears both inside and outside the nucleus [Figure 5], whilst CDATA-M2 is almost entirely localised outside the nucleus of the cell [Figure 6]. Outside the nucleus, neither dye appears to co-localise with lysosomes, but partial colocalisation with mitochondria can be observed. Variation of the concentration of triangulenium dye (0.5-20 $\mu \mathrm{M})$ or time of incubation (4-48 h) yielded no observable difference in localisation [Figures S61-64]. This is in contrast to DAOTA-M2 which, as previously reported, localises primarily inside the nucleus ${ }^{[32]}$. These results demonstrate the significant effect on cellular uptake and localisation, which can result from even minor variations in molecular structure of the fluorophore. 


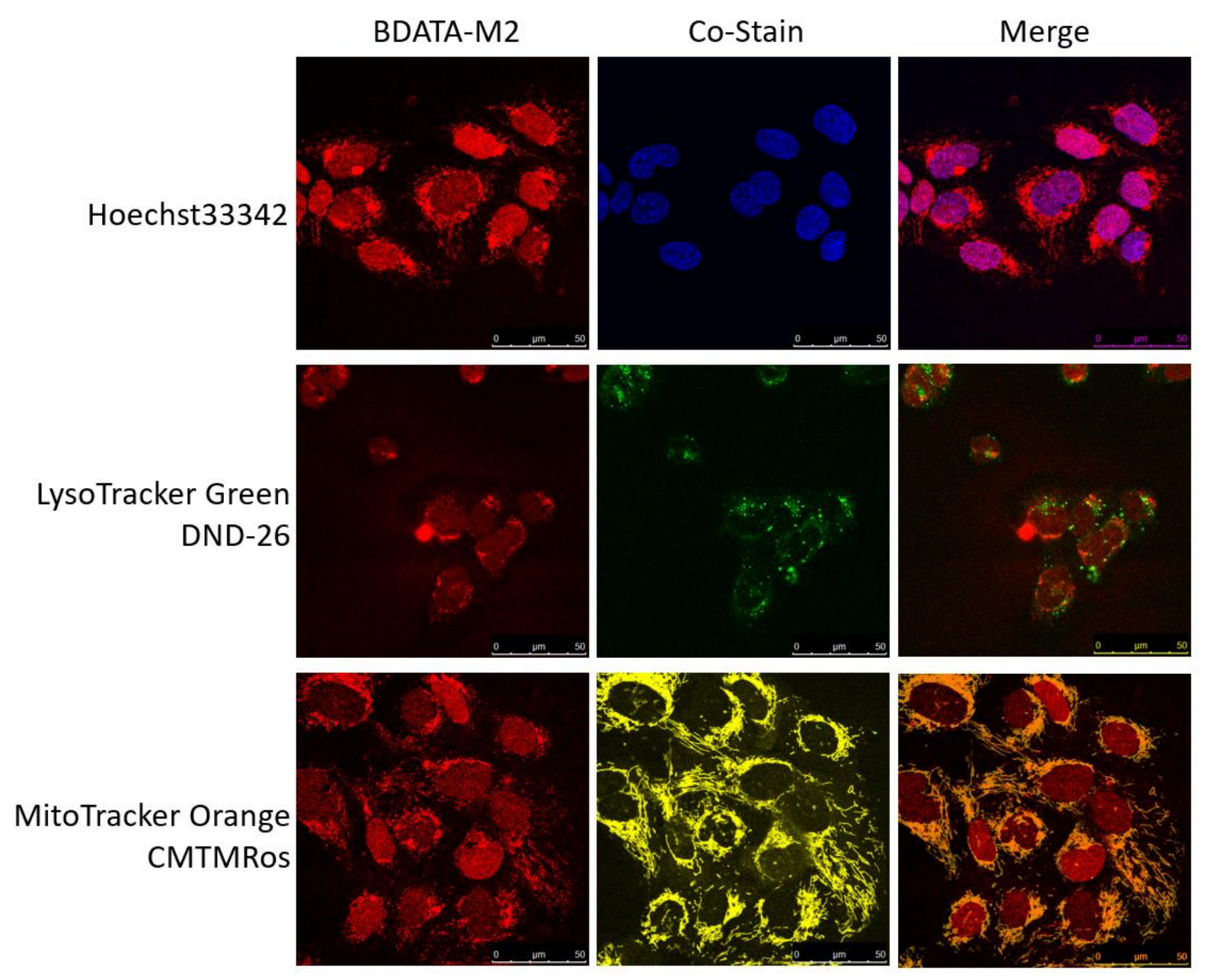

Figure 5. Confocal microscopy images of live U2OS cells stained with BDATA-M2 (10 $\mu \mathrm{M}, 24 \mathrm{~h}$, red) and co-stains for the nucleus (Hoechst 33342, blue), lysosomes (LysoTracker Green DND-26, green) and mitochondria (MitoTracker Orange CMTMRos, Yellow). Experimental details associated with these studies can be found in the Supplementary Information. 


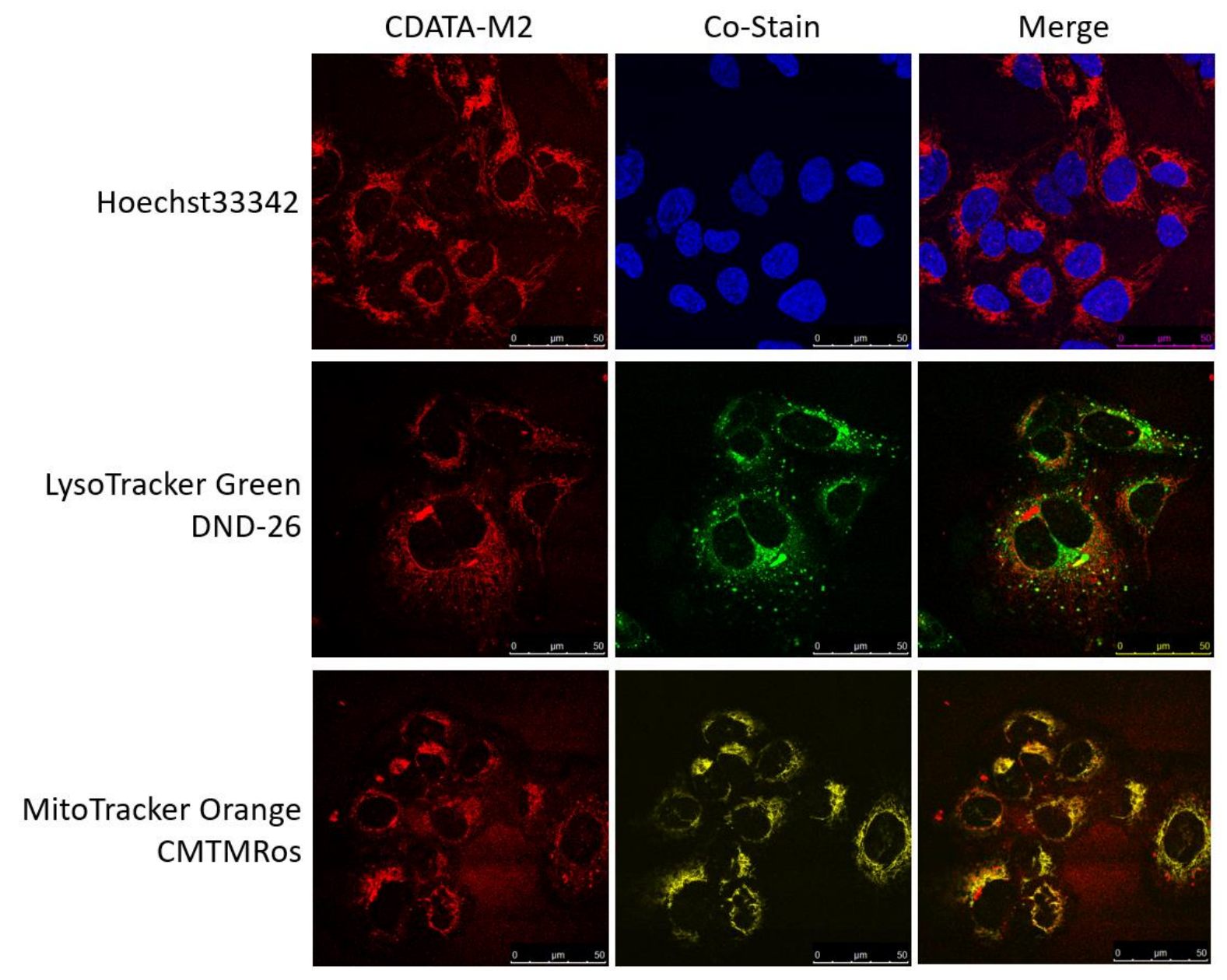

Figure 6. Confocal microscopy images of live U2OS cells stained with CDATA-M2 (10 $\mu \mathrm{M}, 24 \mathrm{~h}$, red) and co-stains for the nucleus (Hoechst 33342, blue), lysosomes (LysoTracker Green DND-26, green) and mitochondria (MitoTracker Orange CMTMRos, Yellow). Experimental details associated with these studies can be found in the Supplementary Information.

For cells stained with BDATA-M2 which showed nuclear localisation, we collected fluorescence lifetime imaging (FLIM) images [Figure S65]. The mean BDATA-M2 lifetime observed in cell nuclei in these images was $9.5 \pm 0.1 \mathrm{~ns}$ which falls in the range of lifetimes observed when BDATA-M2 is incubated with DNA in vitro. This suggests that BDATA-M2 is disaggregated when taken up by live cells and that binding of BDATA-M2 to DNA in the cell nucleus is observable, even if it is unable to discriminate the DNA topologies which are present. CDATA-M2 could not be similarly imaged due to its lack of nuclear staining. 


\section{Conclusions}

New triangulenium dyes with appended morpholino groups, BDATA-M2 and CDATA-M2, were synthesised. Both these new dyes showed fluorescence enhancement upon binding to DNA. BDATA-M2 showed binding affinities for both G4 and dsDNA comparable to the previously reported DAOTA-M2, while CDATA-M2 demonstrates weaker binding to dsDNA whist maintaining similar binding to G4. However, neither BDATA-M2 nor CDATA-M2 could discriminate between these DNA topologies based on their fluorescence lifetime response. With the expectation that PET quenching of the triangulenium core by the morpholino groups

is crucial for a DNA-topology selective response, we found through $\mathrm{pH}$ studies and thermodynamic calculations that CDATA-M2 is less affected by PET than DAOTA-M2, whereas BDATA-M2 may not be quenched through PET at all.

We attribute the fluorescence turn-on for CDATA-M2 to a combination of a relief of PET quenching upon binding and the photophysical changes caused by the hydrophobic environment provided by DNA. The inefficient PET quenching of the CDATA core by the morpholino groups at a neutral $\mathrm{pH}$, in the absence of DNA, seems to be responsible for the moderate fluorescence lifetime enhancement upon binding to G4s and, hence, for the lack of G4 selectivity of this dye.

Our data also indicate that BDATA-M2 aggregates significantly in an aqueous environment, which is consistent with previous observations for other dyes based on the BDATA ${ }^{+}$core. The fluorescence enhancement observed for BDATA-M2 in the presence of various DNA topologies is explained by disaggregation of the dye upon binding to DNA (any topology), rather than the effect of a relief of PET quenching. Consequently, the fluorescence lifetime response of BDATA-M2 was not specific to any DNA topology. 
While these probes are not better DNA dyes than DAOTA-M2, they provide valuable evidence of the delicate interplay between the triangulenium core and the quenching groups needed to obtain the fluorescence lifetime response to selectively image G4-DNA. This added understanding will aid in the development of future probes based on the triangulenium core, which may lead to improved properties as a live cell G4 DNA probe. For example, as compared to DAOTA-M2, the new isopropyl-bridged probe CDATA-M2 displays lower affinity towards duplex DNA without compromising its binding affinity for G4 DNA. While we have not been able to translate this into a better lifetime probe for $\mathrm{G} 4 \mathrm{~s}$, this scaffold provides a promising starting point for more selective probes. It is likely that altering the nature of the substituents and the length of the linker between the core of the probe and the morpholino groups, might lead to a new probe which displays distinct fluorescence lifetimes upon binding to different DNA or RNA topologies.

\section{Experimental}

General Methods: CDOTA $^{+}$and $\mathbf{3}$ were prepared according to literature procedures ${ }^{[37,38]}$. Materials and reagents were otherwise obtained from commercial suppliers and used without further purification. ${ }^{1} \mathrm{H}-\mathrm{NMR},{ }^{13} \mathrm{C}-\mathrm{NMR}$ and $\mathrm{HSQC}$ spectra were acquired on $500 \mathrm{MHz}$ instruments by Bruker fitted with a cryoprobe. Chemical shifts are reported relative to TMS, referenced to the solvent residual for $\mathrm{CD}_{3} \mathrm{CN}\left({ }^{1} \mathrm{H}=1.94 \mathrm{ppm},{ }^{13} \mathrm{C}=1.32 \mathrm{ppm}\right)$. HRMS was recorded on an ESP-MALDI-FT-ICR instrument equipped with a $7 \mathrm{~T}$ magnet (the instrument was calibrated using sodium trifluoroacetate cluster ions prior to acquiring the spectra). Experimental details associated to cell viability and cell imaging studies can be found in the Supplementary Information. 


\section{Synthetic procedures}

\section{4,8-Bis(2-hydroxyethyl)-12,12-dimethyl-8,12-dihydrobenzo[8,1]isoquinolino[3,4,5,6-}

klmn]acridin-3a ${ }^{2}(4 H)$-ylium hexafluorophosphate (1): CDOTA $^{+}(215 \mathrm{mg}, 0.471 \mathrm{mmol})$ and benzoic acid (1.84 g, $15.1 \mathrm{mmol})$ were dissolved in NMP (6 mL). Ethanolamine $(1.00 \mathrm{~mL}, 16.4$ mmol) was added to the red solution which was set to stir at $120^{\circ} \mathrm{C}$. Reaction progress was monitored by MALDI-TOF. After $18 \mathrm{~h}$ another $1.00 \mathrm{~mL}(16.4 \mathrm{mmol})$ of ethanolamine was added and another $0.50 \mathrm{~mL}(8.2 \mathrm{mmol})$ was again added after a total of $48 \mathrm{~h}$. The reaction was allowed to cool to room temperature after $72 \mathrm{~h}$ and poured into swirling $0.2 \mathrm{M} \mathrm{KPF}_{6}(300$ $\mathrm{mL})$. The products were extracted with DCM $(3 \times 100 \mathrm{~mL})$ and the combined organic layers were dried over $\mathrm{MgSO}_{4}$, before the solvent was evaporated under reduced pressure. The crude product was purified by flash column chromatography in acetone and DCM. Fractions containing the product were concentrated and the product was precipitated in diethyl ether from a minimal of DCM. The product was isolated by filtration and washed with diethyl ether to give $150 \mathrm{mg}(59 \%, 0.277 \mathrm{mmol})$ as a blue solid. ${ }^{1} \mathrm{H}-\mathrm{NMR}\left(500 \mathrm{MHz}, \mathrm{CD}_{3} \mathrm{CN}\right): \delta 8.25(\mathrm{t}, \mathrm{J}=$ $8.7 \mathrm{~Hz}, 1 \mathrm{H}), 8.06(\mathrm{dd}, J=8.9,7.5 \mathrm{~Hz}), 7.98(\mathrm{dd}, J=9.0,0.9 \mathrm{~Hz}, 2 \mathrm{H}), 7.87(\mathrm{dd}, J=7.5,0.9 \mathrm{~Hz}$, 2H), $7.62(\mathrm{~d}, J=8.7 \mathrm{~Hz}, 2 \mathrm{H}), 4.83(\mathrm{t}, J=5.9 \mathrm{~Hz}, 4 \mathrm{H}), 4.16(\mathrm{q}, J=5.8 \mathrm{~Hz}, 4 \mathrm{H}), 3.26(\mathrm{t}, J=5.6 \mathrm{~Hz}$, 2H), $1.87(\mathrm{~s}, 6 \mathrm{H}) .{ }^{13} \mathrm{C}-\mathrm{NMR}\left(126 \mathrm{MHz}, \mathrm{CD}_{3} \mathrm{CN}\right): \delta 149.0(-), 143.8(-), 142.3(-), 142.0(-), 139.2$ $(+), 137.2(+), 123.5(+), 116.8(-), 116.6(+), 115.2(-), 106.5(+), 59.1(-), 51.4(-), 41.0(-), 36.6$ (+). HRMS (MALDI-TOF, dithranol matrix): Calcd for $\mathrm{C}_{26} \mathrm{H}_{25} \mathrm{~N}_{2} \mathrm{O}_{2}{ }^{+}\left[\mathrm{M}^{+}\right]$: 397.1916. Found: 397.1887. 


\section{2,12-Dimethyl-4,8-bis(2-(tosyloxy)ethyl)-8,12-dihydro-4H-benzo[8,1]isoquinolino[3,4,5,6-}

klmn]acridin-3a²-ylium-6-ide, hexafluorophosphate (2): Compound 1 (150 mg, 0.277 mmol) and para-toluenesulfonic anhydride (406 mg, $1.24 \mathrm{mmol}$ ) were dissolved in DCM (20 mL). To the blue solution was added trimethylamine $(0.50 \mathrm{~mL}, 5.57 \mathrm{mmol})$ and the resulting solution was stirred at rt. Reaction progress was monitored by MALDI-TOF. After 30 min the reaction was diluted with $\mathrm{DCM}(20 \mathrm{~mL})$ and washed three times with each $0.2 \mathrm{M} \mathrm{KPF} 6$ and water. The organic layer was dried over $\mathrm{Na}_{2} \mathrm{SO}_{4}$ and filtered, before the solvent was evaporated under reduced pressure. The crude material was purified by gravity assisted column chromatography (DCM - iPrOH, 20:1). Fractions containing the product were combined and concentrated and the concentrated solution was poured into swirling diethyl ether $(400 \mathrm{~mL})$. The precipitated product was isolated by filtration and washed with diethyl ether. The blue solid amounted to $90 \mathrm{mg}(38 \%, 0.106 \mathrm{mmol}) .{ }^{1} \mathrm{H}-\mathrm{NMR}\left(500 \mathrm{MHz}, \mathrm{CD}_{3} \mathrm{CN}\right): \delta 8.20(\mathrm{t}, J=8.7 \mathrm{~Hz}$, 1H), 8.08 (dd, $J=8.8,7.6 \mathrm{~Hz}, 2 \mathrm{H}), 7.92(\mathrm{~d}, J=7.6 \mathrm{~Hz}, 2 \mathrm{H}), 7.81(\mathrm{~d}, 8.8 \mathrm{~Hz}, 2 \mathrm{H}), 7.46(\mathrm{~d}, J=8.7$ $\mathrm{Hz}, 2 \mathrm{H}), 7.21(\mathrm{~s} \mathrm{br}, 4 \mathrm{H}), 6.82(\mathrm{~s} \mathrm{br}, 4 \mathrm{H}), 5.01(\mathrm{~s}, 4 \mathrm{H}), 4.77(\mathrm{t}, J=5.2 \mathrm{~Hz}, 4 \mathrm{H}), 1.86(\mathrm{~s} \mathrm{br}, 6 \mathrm{H})$. (Note: OTs methyl signals are under solvent; they can be seen by HSQC - see supplementary information). ${ }^{13} \mathrm{C}-\mathrm{NMR}\left(126 \mathrm{MHz}, \mathrm{CD}_{3} \mathrm{CN}\right): \delta 149.2(-), 146.2(-), 143.9(-), 141.5(-), 141.4(-$ ),139.6 (+), $137.8(+), 132.8(-), 130.4(+), 128.2(+), 124.1(+), 116.0(-), 115.2(+), 114.9(-)$, $106.6(+), 67.6(+), 47.5(-), 41.0(-), 30.7(+), 21.2(+)$. (Note: OTs methyl signals are under solvent; they can be seen by HSQC - see supplementary information). HRMS (MALDI-TOF, dithranol matrix): Calcd for $\mathrm{C}_{40} \mathrm{H}_{37} \mathrm{~N}_{2} \mathrm{O}_{6} \mathrm{~S}_{2}{ }^{+}\left[\mathrm{M}^{+}\right]$: 705.2088. Found: 705.2097. $\mathrm{R}_{\mathrm{f}}\left(\mathrm{DCM}-{ }^{i} \mathrm{PrOH}\right.$, $20: 1)=0.7$. 


\section{2,12-Dimethyl-4,8-bis(2-morpholinoethyl)-8,12-dihydrobenzo[8,1]isoquinolino[3,4,5,6-}

klmn]acridin-3a ${ }^{2}(4 H)$-ylium hexafluorophosphate (CDATA-M2): From 2: Compound 2 (130 $\mathrm{mg}, 0.153 \mathrm{mmol})$, morpholine $(0.213 \mathrm{~mL}, 2.44 \mathrm{mmol})$ and triethylamine $(0.50 \mathrm{~mL}, 3.49 \mathrm{mmol})$ were dissolved in acetonitrile $(20 \mathrm{~mL})$ and heated to reflux. Reaction progress was monitored by MALDI-TOF. After $24 \mathrm{~h}$ another $0.107 \mathrm{~mL}(1.22 \mathrm{mmol})$ of morpholine and $0.20 \mathrm{~mL}$ (1.74 $\mathrm{mmol}$ ) of triethylamine were added. After $72 \mathrm{~h}$ the reaction was allowed to cool to room temperature and poured into swirling $0.2 \mathrm{M} \mathrm{KPF}_{6}(300 \mathrm{~mL})$. The products were extracted with DCM and concentrated. The crude material was purified by flash column chromatography (DCM - iPrOH, 19:1). Fractions containing the product were combined and the solvent was evaporated under reduced pressure to give $58 \mathrm{mg}(56 \%, 0.085 \mathrm{mmol})$ of the product as a blue solid.

From CDOTA+: 2-Morpholinoethylamine (1.73 mL, $13.2 \mathrm{mmol}$ ) was added to a solution of CDOTA (100 mg, $0.219 \mathrm{mmol}$ ) and benzoic acid (1.61 g, $13.2 \mathrm{mmol})$ in NMP (5 mL) in a roundbottomed flask. The solution turned colorless and precipitation was observed. The mixture was heated to $70^{\circ} \mathrm{C}$ on an oil bath and reaction progress was followed by MALDI-TOF. The reaction mixture had turned purple after $30 \mathrm{~min}$. After 7 days the dark green reaction mixture was quenched by cooling to room temperature and poured into basic $(\mathrm{pH}=10)$ swirling $0.2 \mathrm{M}$ $\mathrm{KPF}_{6}$. The resulting dark green precipitate was isolated by filtration and washed off the filter with DCM. The solvent was evaporated under reduced pressure and the blue residue was triturated with diethyl ether. The product was purified by gravity assisted column chromatography, first with DCM-acetone (9:1) and after the pink impurity had eluted the eluent was switched to MeCN-water-triethylamine (69:30:1) to elute the blue product. The solvents were evaporated under reduced pressure to give the product as a blue solid ( $1 \mathrm{mg}$, $<1 \%) .{ }^{1} \mathrm{H}-\mathrm{NMR}\left(500 \mathrm{MHz}, \mathrm{CD}_{3} \mathrm{CN}\right): \delta 8.29(\mathrm{t}, J=8.6 \mathrm{~Hz}, 1 \mathrm{H}), 8.08(\mathrm{dd}, J=8.9,7.6 \mathrm{~Hz}, 2 \mathrm{H}), 7.92-$ 
$7.87(\mathrm{~m}, 4 \mathrm{H}), 7.56(\mathrm{~d}, J=8.7 \mathrm{~Hz}, 2 \mathrm{H}), 4.77(\mathrm{~s} \mathrm{br}, 4 \mathrm{H}), 3.64(\mathrm{t}, J=4.7 \mathrm{~Hz}, 8 \mathrm{H}), 2.95(\mathrm{t}, J=7.1 \mathrm{~Hz}$, 4H), 2.65-2.57 (m, 8H), $1.87(\mathrm{~s}, 6 \mathrm{H}) .{ }^{13} \mathrm{C}-\mathrm{NMR}\left(126 \mathrm{MHz}, \mathrm{CD}_{3} \mathrm{CN}\right): \delta 149.2(-), 143.7(-), 142.0(-$ ), $141.5(-), 139.5(+), 137.4(+), 123.6(+), 116.7(-), 115.3(-), 115.2(+), 106.2(+), 67.6(-), 55.0$ $(-), 54.9(-), 48.1(-), 41.1(-), 36.5(+)$. HRMS (MALDI-TOF, dithranol matrix): Calcd for $\mathrm{C}_{34} \mathrm{H}_{39} \mathrm{~N}_{4} \mathrm{O}_{2}{ }^{+}\left[\mathrm{M}^{+}\right]:$535.3068. Found: 535.3024.

\section{3,7-Bis(2-hydroxyethyl)-11-methoxy-3,7-dihydro-11bH-benzo[a]quinolino[2,3,4-kl]acridin-}

11b-ylium hexafluorophosphate (4): 12-(2,6-dimethoxyphenyl)-11-methoxy-12Hbenzo[a]xanthen-12-ylium hexafluorophosphate (3) $(510 \mathrm{mg}, 0.940 \mathrm{mmol}$ ) and benzoic acid (3.44 g, $28.2 \mathrm{mmol})$ were dissolved in NMP (8 mL). Ethanolamine $(1.80 \mathrm{~mL}, 29.5 \mathrm{mmol})$ was added to the red solution and the resulting solution was stirred at $100^{\circ} \mathrm{C}$. Reaction progress was monitored by MALDI-TOF. After $32 \mathrm{~h}$ another $0.90 \mathrm{~mL}(14.8 \mathrm{mmol})$ of ethanolamine was added to the reaction. After $80 \mathrm{~h}$ the reaction was allowed to cool to room temperature and poured into swirling 0.2 $\mathrm{M} \mathrm{KPF}_{6}(200 \mathrm{~mL})$. The products were extracted with $\mathrm{DCM}$. The solvent was removed by evaporation under reduced pressure and the crude material was purified by flash column chromatography (DCM - $\left.{ }^{i} \mathrm{PrOH}, 20: 1\right)$. Fractions containing the product were combined and the solvent was evaporated under reduced pressure to give $120 \mathrm{mg}$ ( $22 \%$, $0.206 \mathrm{mmol})$ as a blue solid. ${ }^{1} \mathrm{H}-\mathrm{NMR}\left(500 \mathrm{MHz}, \mathrm{CD}_{3} \mathrm{CN}\right): \delta 8.35(\mathrm{~d}, J=9.4 \mathrm{~Hz}, 1 \mathrm{H}), 8.20(\mathrm{t}, J=$ $8.6 \mathrm{~Hz}, 1 \mathrm{H}), 8.11(\mathrm{~d}, J=9.6 \mathrm{~Hz}, 1 \mathrm{H}), 8.03(\mathrm{dd}, J=8.1,1.4 \mathrm{~Hz}, 1 \mathrm{H}), 7.90-7.83(\mathrm{~m}, 3 \mathrm{H}), 7.80(\mathrm{~d}, J$ $=8.5 \mathrm{~Hz}, 1 \mathrm{H}), 7.63-7.58(\mathrm{~m}, 2 \mathrm{H}), 7.38-7.33(\mathrm{~m}, 1 \mathrm{H}), 6.72(\mathrm{~d}, J=8.0 \mathrm{~Hz}, 1 \mathrm{H}), 5.04(\mathrm{dt}, J=15.8$, $5.4 \mathrm{~Hz}, 1 \mathrm{H}), 4.92-4.82(\mathrm{~m}, 2 \mathrm{H}), 4.69(\mathrm{dt}, J=15.7,6.2 \mathrm{~Hz}, 1 \mathrm{H}), 4.25-4.15(\mathrm{~m}, 4 \mathrm{H}), 3.29(\mathrm{q}, J=5.6$ $\mathrm{Hz}, 2 \mathrm{H}), 2.90(\mathrm{~s}, 3 \mathrm{H}) .{ }^{13} \mathrm{C}-\mathrm{NMR}\left(126 \mathrm{MHz}, \mathrm{CD}_{3} \mathrm{CN}\right): \delta 158.6(-), 144.4(-), 143.6(-), 143.2(-)$, $140.3(-), 139.8(-), 138.9(+), 137.7(+), 136.2(+), 133.0(-), 129.5(+), 129.3(-), 129.0(+), 128.6$ 
(+), $122.1(+), 121.6(-), 116.5(+), 112.9(-), 110.2(+), 107.9(+), 107.8(+), 105.6(+), 59.9(-)$, $59.3(-), 55.6(+), 52.5(-), 52.5$ (-). HRMS (MALDI-TOF, dithranol matrix): Calcd for $\mathrm{C}_{28} \mathrm{H}_{25} \mathrm{~N}_{2} \mathrm{O}_{3}{ }^{+}$ $\left[\mathrm{M}^{+}\right]$: 437.1865. Found: 437.1831.

\section{1-Methoxy-3,7-bis(2-(tosyloxy)ethyl)-3,7-dihydro-11bH-benzo[a]quinolino[2,3,4-}

kl]acridin-11b-ylium hexafluorophosphate (5): 4 (70 $\mathrm{mg}, 0.12 \mathrm{mmol}$ ) and para-toluene sulfonic anhydride $(235 \mathrm{mg}, 0.721 \mathrm{mmol})$ were dissolved in DCM $(20 \mathrm{~mL})$. Triethylamine $(0.50$ $\mathrm{mL}, 3.49 \mathrm{mmol}$ ) was added and the resulting blue solution was stirred at rt. Reaction progress was monitored by MALDI-TOF. After $16 \mathrm{~h}$ the reaction was diluted with DCM $(20 \mathrm{~mL})$ and washed three times with each $0.2 \mathrm{M} \mathrm{KPF}_{6}$ and water. The organic layer was dried over $\mathrm{Na}_{2} \mathrm{SO}_{4}$, before being filtered. The solvents were evaporated under reduced pressure and the crude material was purified by gravity assisted column chromatography (DCM - $i \operatorname{PrOH}, 20: 1$ ). Fractions containing the product were combined and concentrated under reduced pressure. The highly concentrated solution was poured into swirling diethyl ether (400 $\mathrm{mL})$. The resulting blue precipitate was isolated by filtration and washed with diethyl ether to give 47 $\mathrm{mg}(44 \%, 0.053 \mathrm{mmol})$ of the product. ${ }^{1} \mathrm{H}-\mathrm{NMR}\left(500 \mathrm{MHz}, \mathrm{CD}_{3} \mathrm{CN}\right): \delta 8.33(\mathrm{~d}, J=9.5 \mathrm{~Hz}, 1 \mathrm{H})$, $8.17(\mathrm{t}, J=8.5 \mathrm{~Hz}, 1 \mathrm{H}), 8.05(\mathrm{dd}, J=7.9,1.3 \mathrm{~Hz}, 1 \mathrm{H}), 7.92-7.85(\mathrm{~m}, 2 \mathrm{H}), 7.78(\mathrm{~d}, J=8.5 \mathrm{~Hz}, 1 \mathrm{H})$, 7.68-7.60 (m, 3H), 7.44-7.36 (m, 2H), $7.23(\mathrm{~d}, J=7.9 \mathrm{~Hz}, 2 \mathrm{H}), 7.17(\mathrm{~d}, J=8.0 \mathrm{~Hz}, 2 \mathrm{H}), 6.78(\mathrm{~d}, J$ $=7.9 \mathrm{~Hz}, 2 \mathrm{H}), 6.74(\mathrm{~d}, J=8.0 \mathrm{~Hz}, 1 \mathrm{H}), 6.68(\mathrm{~d}, J=7.9 \mathrm{~Hz}, 2 \mathrm{H}), 5.23-4.69(\mathrm{~m}, 8 \mathrm{H}), 2.91(\mathrm{~s}, 3 \mathrm{H})$, $1.89(\mathrm{~s}, 3 \mathrm{H})$. (Note: one -OTs methyl signal is located under solvent; it can be seen by HSQC see Supplementary Information). ${ }^{13} \mathrm{C}-\mathrm{NMR}\left(126 \mathrm{MHz}, \mathrm{CD}_{3} \mathrm{CN}\right): \delta 158.7(-), 146.2(-), 143.7(-)$, $143.5(-), 139.6(+), 139.6(-), 139.0(-), 138.3(+), 136 .(+), 136.3(-), 132.8(-), 132.3(-), 130.6$ $(-), 130.4(+), 130.3(+), 129.7(+), 129.4(+), 129.1(-), 129.0(+), 128.1(+), 128.1(+), 122.1(+)$, 
$115.6(+), 109.6(+), 108.0(+), 107.7(+), 106.1(+), 67.7(-), 67.6(-), 55.7(+), 21.3(+), 21.2(+)$.

(Signals for $\mathrm{N}$-side chain $\alpha$-carbon missing; they can be seen by HSQC - see Supplementary Information). HRMS (MALDI-TOF, dithranol matrix): Calcd for $\mathrm{C}_{42} \mathrm{H}_{37} \mathrm{~N}_{2} \mathrm{O}_{7} \mathrm{~S}_{2}^{+}\left[\mathrm{M}^{+}\right]$: 745.2037. Found: 745.2045.

\section{1-Methoxy-3,7-bis(2-morpholinoethyl)-3,7-dihydro-11bH-benzo[a]quinolino[2,3,4-}

kl]acridin-11b-ylium hexafluorophosphate (6): Triethylamine $(0.5 \mathrm{~mL}, 3.6 \mathrm{mmol})$ was added to a blue solution of $5(47 \mathrm{mg}, 0.053 \mathrm{mmol})$ in acetonitrile $(10 \mathrm{~mL})$. Morpholine $(0.4 \mathrm{~mL}, 4.6$ mmol) was then added and the resulting solution was heated to reflux. Reaction progress was followed by MALDI-TOF. After $18 \mathrm{~h}$ the reaction was quenched by pouring the acetonitrile solution into swirling $0.2 \mathrm{M} \mathrm{KPF}_{6}(300 \mathrm{~mL})$. The product was extracted with $\mathrm{DCM}$ and the volatile organics were subsequently evaporated under reduced pressure. The crude material was purified by flash column chromatography (DCM - iPrOH, 19:1). Fractions containing the product were combined and the solvent was evaporated under reduced pressure to give 16 $\mathrm{mg}(42 \%, 0.022 \mathrm{mmol})$ of the product as a blue solid. ${ }^{1} \mathrm{H}-\mathrm{NMR}\left(500 \mathrm{MHz}, \mathrm{CD}_{3} \mathrm{CN}\right): \delta 8.38$ (d, $J$ $=9.5 \mathrm{~Hz}, 1 \mathrm{H}), 8.22(\mathrm{t}, J=8.5 \mathrm{~Hz}, 1 \mathrm{H}), 8.09-8.02(\mathrm{~m}, 2 \mathrm{H}), 7.93-7.87(\mathrm{~m}, 2 \mathrm{H}), 7.79(\mathrm{~d}, J=8.5 \mathrm{~Hz}$, $1 \mathrm{H}), 7.74(\mathrm{~d}, J=8.5 \mathrm{~Hz}, 1 \mathrm{H}), 7.64-7.56(\mathrm{~m}, 2 \mathrm{H}), 7.37(\mathrm{ddd}, J=8.4,7.0,1.4 \mathrm{~Hz}, 1 \mathrm{H}), 6.73(\mathrm{~d}, J=$ $8.1 \mathrm{~Hz}, 1 \mathrm{H}), 5.07-4.97(\mathrm{~m}, 1 \mathrm{H}), 4.90-4.77(\mathrm{~m}, 2 \mathrm{H}), 4.72-4.61(\mathrm{~m}, 1 \mathrm{H}), 3.67-3.46(\mathrm{~m}, 8 \mathrm{H}), 3.05-$ $2.96(\mathrm{~m}, 4 \mathrm{H}), 2.92(\mathrm{~s}, 3 \mathrm{H}), 2.56(\mathrm{~s} \mathrm{br}, 8 \mathrm{H}) .{ }^{13} \mathrm{C}-\mathrm{NMR}\left(126 \mathrm{MHz}, \mathrm{CD}_{3} \mathrm{CN}\right): \delta 158.6(-), 144.0(-)$, $143.2(-), 143.1(-), 140.0(-), 139.6(-), 139.1(+), 137.8(+), 136.4(+), 132.9(-), 129.6(+), 129.4$ $(-), 129.0(+), 128.6(+), 122.2(+), 121.8(-), 116.4(+), 114.0(-), 113.2(-), 110.0(+), 107.6(+)$, $107.4(+), 105.7(+), 67.6(-), 67.5(-), 56.1(-), 55.6(+), 55.4(-), 54.8(-)$. (Signals for $N$-side chain 
a-carbon missing; they can be seen by HSQC - see Supplementary Information). HRMS (MALDI-TOF, dithranol matrix): Calcd for $\mathrm{C}_{36} \mathrm{H}_{39} \mathrm{~N}_{4} \mathrm{O}_{3}{ }^{+}\left[\mathrm{M}^{+}\right]$: 575.3017. Found: 575.3024 .

\section{7,11-Bis(2-morpholinoethyl)-7,11-dihydro-3b² $\mathrm{H}$ -}

naphtho[8',1',2':7,8,1]isoquinolino[3,4,5,6-klmn]acridin-3b²-ylium hexafluorophosphate (BDATA-M2): Phosphorous pentoxide $\left(1.85 \mathrm{~g}, 6.52 \mathrm{mmol}\left[\mathrm{P}_{4} \mathrm{O}_{10}\right]\right.$ ) was added to $85 \% \mathrm{H}_{3} \mathrm{PO}_{4}$ $(1.0 \mathrm{~mL}, 15 \mathrm{mmol})$ in small portions in a dry round-bottomed flask under moderate stirring. The flask was fitted with a $\mathrm{N}_{2}$-bubbler and heated to $110^{\circ} \mathrm{C}$ for about $1 \mathrm{~h}$ on an oil bath. The bubbler was then removed and $6(7.6 \mathrm{mg}, 0.011 \mathrm{mmol})$ was added. The flask was covered with a watch glass and reaction progress was monitored by MALDI-TOF. The bluish-green mixture was kept at $110^{\circ} \mathrm{C}$ for $44 \mathrm{~h}$ under mild stirring before the flask was removed from the oil bath to cool to room temperature. The viscous reaction mixture was quenched by transfer to $0.2 \mathrm{M} \mathrm{KPF}_{6}(50 \mathrm{~mL})$ and $1 \mathrm{M} \mathrm{NaOH}(70 \mathrm{~mL})$ was added to neutralize the resulting aqueous phase. The product was extracted with DCM $(5 \times 10 \mathrm{~mL})$. The combined organic layers were washed with water $(50 \mathrm{~mL})$ and brine $(50 \mathrm{~mL})$ before being dried over $\mathrm{MgSO}_{4}$. The desiccant was removed by filtration and the solvent was evaporated under reduced pressure. The resulting greenish-blue solid was reprecipitated in $\mathrm{Et}_{2} \mathrm{O}(10 \mathrm{~mL})$ from acetonitrile $(1 \mathrm{~mL})$ and washed with $\mathrm{Et}_{2} \mathrm{O}(3 \times 2 \mathrm{~mL})$. The product was dissolved in $\mathrm{DCM}(5 \mathrm{~mL})$ and the blue solution was filtered through a $0.22 \mu \mathrm{m}$ PTFE filter. The solvent was evaporated under reduced pressure to give $2.2 \mathrm{mg}$ (30\%) of the product as a greenish-blue solid. ${ }^{1} \mathrm{H}-\mathrm{NMR}(500 \mathrm{MHz}$, $\left.\mathrm{CD}_{3} \mathrm{CN}\right): \delta 8.73(\mathrm{~d}, \mathrm{~J}=7.9,1 \mathrm{H}), 8.48(\mathrm{~d}, \mathrm{~J}=9.4,1 \mathrm{H}), 8.27-8.20(\mathrm{~m}, 3 \mathrm{H}), 8.06-7.99(\mathrm{~m}, 2 \mathrm{H}), 7.91$ $(t, J=7.7,1 H), 7.63(d, J=8.7,1 H), 7.58(d, J=8.5,1 H), 7.47(d, J=8.5,1 H), 4.83(s ~ b r, 2 H), 4.42(t$, $\mathrm{J}=7.5,2 \mathrm{H}), 3.69(\mathrm{~s} \mathrm{br}, 2 \mathrm{H}), 3.57(\mathrm{~s} \mathrm{br}, 2 \mathrm{H}), 2.94(\mathrm{t}, \mathrm{J}=6.8,2 \mathrm{H}), 2.84(\mathrm{t}, \mathrm{J}=7.3,2 \mathrm{H}), 2.66(\mathrm{~s} \mathrm{br}, 4 \mathrm{H})$, 
2.58 (s br, 4H). ${ }^{13} \mathrm{C}-\mathrm{NMR}\left(126 \mathrm{MHz}, \mathrm{CD}_{3} \mathrm{CN}\right): \delta 143.6(-), 142.3(-), 141.7(-), 140.7(+), 139.4(-$ ), $138.7(-), 137.6(+), 136.3(+), 134.5(-), 132.1(+), 129.2(+), 128.9(-), 128.3(-), 127.4(+)$, $123.1(-), 117.7(+), 117.5(-), 117.0(+), 116.9(-), 113.5(+), 111.6(-), 107.7(+), 107.5(+), 67.6$ $(-), 67.5(-), 55.5(-), 55.0(-), 54.9(-), 54.2(-), 48.7(-), 47.1(-)$. HRMS (ESP): Calcd for $\mathrm{C}_{36} \mathrm{H}_{39} \mathrm{~N}_{4} \mathrm{O}_{3}{ }^{+}\left[\mathrm{M}^{+}\right]:$543.2760. Found: 543.2757.

Oligonucleotides: DNA sequences used in this work are listed in Table 2. Oligonucleotides were purchased from Kaneka Eurogentec S.A. (Belgium) as lyophilised solids (RP-Cartridge Gold purification) and dissolved in $10 \mathrm{mM}$ lithium cacodylate buffer containing $100 \mathrm{mM}$ potassium chloride. Deoxyribunucleic acid sodium salt from calf thymus DNA (CT-DNA) was bought from Merck KGaA (Germany). DNA concentration was determined using the absorbance at $260 \mathrm{~nm}$ and the extinction coefficient supplied by the manufacturer. DNA annealing was performed by heating samples to $95^{\circ} \mathrm{C}$ for 5 mins followed by slow cooling to room temperature.

Table 2. DNA oligonucleotide sequences used in this work

\begin{tabular}{|l|l|l|}
\hline Name & Sequence $\mathbf{( 5}^{\prime} \mathbf{- 3}^{\mathbf{\prime}} \mathbf{)}$ & Structure \\
\hline c-myc & TGAGGGTGGGTAGGGTGGGTAA & Parallel G4 ${ }^{[48]}$ \\
\hline HT-G4 & TTGGGTTAGGGTTAGGGTTAGGGA & Hybrid G4 $^{[49]}$ \\
\hline HRAS-1 & TCGGGTTGCGGGCGCAGGGCACGGGCG & Anti-parallel G4 $^{[50]}$ \\
\hline 22AG & AGGGAGGGCGCTGGGAGGAGGG & Snap-back parallel G4 ${ }^{[51]}$ \\
\hline ds17 & AGGGTTAGGGTTAGGGTTAGGG & Parallel G4 ${ }^{[52]}$ \\
& Equimolar mixture of: & dsDNA \\
\hline & Strand 1 - CCAGTTCGTAGTAACCC; & \\
\hline
\end{tabular}




\begin{tabular}{|l|l|l|}
\hline & Strand 2 - GGGTTACTACGAACTGG & \\
\hline ds17 strand 1 & CCAGTTCGTAGTAACCC & ssDNA \\
\hline$d($ AT)8 & ATATATATATATATAT & ssDNA \\
\hline
\end{tabular}

DNA titrations: Absorbance measurements were performed using an 8453 UV-Visible Spectroscopy System (Agilent) or a Cary 60 UV-Vis Spectrometer (Agilent). All fluorescence measurements were measured using a Fluoromax-4 spectrofluorimeter (Jobin-Yvon; Horiba).

The dye being studied was prepared in $10 \mathrm{mM}$ lithium cacodylate buffer containing $100 \mathrm{mM}$ potassium chloride in a quartz cuvette of $1 \mathrm{~cm}$ pathlength. Approx. $20 \mu \mathrm{M}$ initial concentration of dye was used for absorption titrations and approx. $2 \mu \mathrm{M}$ initial concentration was used for fluorescence titrations, except for ds17 with CDATA-M2 where $0.5 \mu$ M CDATAM2 was used to achieve a sufficiently high DNA base pair equivalence. Aliquots of DNA solution prepared in the same buffer were added until DNA was present in significant excess. For absorption titrations, a blank measurement of the cuvette and buffer only without dye or DNA was recorded and subtracted from the measured absorptions. Stoichiometry of binding was determined by the change in gradient of the absorption titration curve (mole ratio method $^{[53]}$ ). For BDATA-M2, absorption was plotted at $633 \mathrm{~nm}$ relative to the absorption peak at 590-595 $\mathrm{nm}$ to account for the effect of disaggregation. To get good fits for binding affinity, BDATA-M2 bound to G4-DNA was plotted as absolute absorption at $633 \mathrm{~nm}$ with initial points where absorption falls due to effect of disaggregation removed from the analysis. For CDATAM2, absorption was plotted at $595 \mathrm{~nm}$.

For fluorescence-based titrations, three independent repeats were performed. For CDATAM2 the sample was excited at $607 \mathrm{~nm}$ where change in absorption with addition of DNA is 
minimal. Fluorescence was collected $615-800 \mathrm{~nm}$. For the purpose of fitting the data, fluorescence was integrated over 615-650 nm. For BDATA-M2, the sample was excited at 580 $\mathrm{nm}$ and fluorescence was collected $590-800 \mathrm{~nm}$. Due to changes of absorption over the course of the titration for this dye, an absorbance spectrum was acquired for each data point and the integrated emission was corrected for changes in absorbance.

Titration curves were individually fitted using the 1:1 binding model using a MatLab script previously reported, ${ }^{[54]}$ or in OriginPro using the same method, to determine binding constants. For emission titrations, the binding constant for each titration was fitted individually and the average value reported alongside the standard deviation. In figures, the average of the three titrations has been fitted and shown. The binding constants are reported relative to the stoichiometry of binding by multiplying the fitted binding constant by the stoichiometry determined by absorption titration. For CDATA-M2, stoichiometry of binding was two compounds to one G-quadruplex and one compound to four base pairs for dsDNA. For BDATA-M2, stoichiometry of binding was two compounds to one G-quadruplex, one compound to five base pairs for CT-DNA and two compounds to three base pairs for ds17.

Fluorescence lifetime determination: Time resolved fluorescence traces were recorded with time-correlated single-photon counting (TCSPC) using either an IBH 5000F TCSPC device (Jobin Ybon, Horiba) equipped with a $404 \mathrm{~nm}$ NanoLED as an excitation source (pulse width < 200 ps, HORIBA) (BDATA-M2) or using a home-built TCSPC setup previously described ${ }^{[55]}$ with a pulsed diode laser at $477 \mathrm{~nm}$ (Becker \& Hickl GmbH, 20MHz) (CDATA-M2).

Time-resolved fluorescence decays were acquired with detection at $660 \mathrm{~nm}( \pm 16 \mathrm{~nm})$ after passing through a $645 \mathrm{~nm}$ long pass filter (BDATA-M2) or at $640 \mathrm{~nm}( \pm 15 \mathrm{~nm})$ after passing through a $550 \mathrm{~nm}$ long pass filter (CDATA-M2). Decays were accumulated to at least 10000 
counts. Instrument response function was measured using a Ludox solution, detecting the emission near the excitation wavelength. Traces were fitted to a biexponential equation and the intensity-weighted average fluorescence lifetime was calculated using the equation:

$$
\tau_{\text {intensity-weighted }}=\frac{\tau_{1}^{2} \alpha_{1}+\tau_{2}^{2} \alpha_{2}}{\tau_{1} \alpha_{1}+\tau_{2} \alpha_{2}}
$$

Where $\tau_{n}$ are the respective lifetime components and $\alpha_{n}$ are the respective amplitudes. For CDATA-M2, data were fitted using the FLIMFit software tool developed at Imperial College London (v5.1.1, Sean Warren, Imperial College London). For BDATA-M2, data were fitted using DAS-6 software (Horiba).

Samples for the above measurements were prepared at approx. $2 \mu \mathrm{M}$ dye concentration in a quartz cuvette. For CDATA-M2, 5 strand equivalents of each DNA oligonucleotide were used or 50 base pair equivalents of CT-DNA. For BDATA-M2, 1 strand equivalent of G4-DNAs or 5 base/base pair equivalents of non-G4-DNA was used.

\section{Conflicts of interest}

The authors declare the following competing financial interests: Bo W. Laursen is associated with the company KU-dyes, which produces and sells fluorescent dyes (including triangulenium dyes).

\section{Acknowledgements}

BWL (Benjamin W. Lewis) is thankful to the UK Engineering and Physical Sciences Research Council (EPSRC EP/L015498/1) for a studentship as part of the Centre of Doctoral Training. 
RV, MKK, JBV and PAS acknowledge the financial support of the Excellence Fund for Frontier Research, Imperial College London. BWL (Bo W. Laursen) and NB acknowledge the financial support of the Danish Council of Independent Research (DFF-6111-00483).

\section{References}

1 A. N. Lane, J. B. Chaires, R. D. Gray, J. O. Trent, Nucleic Acids Res., 2008, 36, 54825515.

2 S. Burge, G. N. Parkinson, P. Hazel, A. K. Todd, S. Neidle, Nucleic Acids Res., 2006, 34, 5402-5415.

3 L. Stefan, D. Monchaud, Nat. Rev. Chem., 2019, 3, 650-668.

4 D. Rhodes, H. J. Lipps, Nucleic Acids Res., 2015, 43, 8627-37.

5 M. L. Bochman, K. Paeschke, V. A. Zakian, Nat Rev Genet, 2012, 13, 770-780.

6 P. Murat, S. Balasubramanian, Curr. Opin. Genet. Dev., 2014, 25, 22-29.

7 D. Varshney, J. Spiegel, K. Zyner, D. Tannahill, S. Balasubramanian, Nat. Rev. Mol. Cell Biol., , DOI:10.1038/s41580-020-0236-x.

8 C. K. Kwok, C. J. Merrick, Trends Biotechnol., 2017, 35, 997-1013.

9 F. Raguseo, S. Chowdhury, A. Minard, M. Di Antonio, Chem. Commun., 2020, 56, $1317-1324$.

10 J. L. Huppert, S. Balasubramanian, Nucleic Acids Res., 2005, 33, 2908-2916.

11 A. K. Todd, M. Johnston, S. Neidle, Nucleic Acids Res., 2005, 33, 2901-2907. 
Balasubramanian, Nat. Biotechnol., 2015, 33, 877-883.

13 R. Hänsel-Hertsch, D. Beraldi, S. V Lensing, G. Marsico, K. Zyner, A. Parry, M. Di Antonio, J. Pike, H. Kimura, M. Narita, D. Tannahill, S. Balasubramanian, Nat. Genet., 2016, 48, 1267-72.

14 A.-L. Valton, M.-N. Prioleau, Trends Genet., 2016, 32, 697-706.

15 D. Sen, W. Gilbert, Nature, 1988, 334, 364-366.

16 L. T. Gray, A. C. Vallur, J. Eddy, N. Maizels, Nat. Chem. Biol., 2014, 10, 313-8.

17 A. Bugaut, S. Balasubramanian, Nucleic Acids Res., 2012, 40, 4727-4741.

18 A. Verma, K. Halder, R. Halder, V. K. Yadav, P. Rawal, R. K. Thakur, F. Mohd, A. Sharma, S. Chowdhury, J. Med. Chem., 2008, 51, 5641-5649.

19 E. A. Raiber, R. Kranaster, E. Lam, M. Nikan, S. Balasubramanian, Nucleic Acids Res., 2012, 40, 1499-1508.

20 C. Schaffitzel, I. Berger, J. Postberg, J. Hanes, H. J. Lipps, A. Plückthun, Proc. Natl. Acad. Sci. U. S. A., 2001, 98, 8572-7.

21 E. Henderson, C. C. Hardin, S. K. Walk, I. Tinoco, E. H. Blackburn, Cell, 1987, 51, 899908.

22 W. I. Sundquist, A. Klug, Nature, 1989, 342, 825-829.

23 A. M. Zahler, J. R. Williamson, T. R. Cech, D. M. Prescott, Nature, 1991, 350, 718-720.

24 N. Maizels, EMBO Rep., 2015, 16, 1-13. 
25 S. Neidle, G. Parkinson, Nat. Rev. Drug Discov., 2002, 1, 383-93.

26 S. Balasubramanian, L. H. Hurley, S. Neidle, Nat. Rev. Drug Discov., 2011, 10, 261-75.

27 S. Neidle, Nat. Rev. Chem., 2017, 1, 0041.

28 S. Asamitsu, S. Obata, Z. Yu, T. Bando, H. Sugiyama, Molecules, 2019, 24, 429.

29 G. Biffi, D. Tannahill, J. McCafferty, S. Balasubramanian, Nat. Chem., 2013, 5, 182-6.

30 D. Monchaud, arXiv, 2019, arXiv:1910.07023 [q-bio.BM].

31 M. Di Antonio, A. Ponjavic, A. Radzevičius, R. T. Ranasinghe, M. Catalano, X. Zhang, J. Shen, L. M. Needham, S. F. Lee, D. Klenerman, S. Balasubramanian, Nat. Chem., , DOI:10.1038/s41557-020-0506-4.

32 A. Shivalingam, M. A. Izquierdo, A. Le Marois, A. Vyšniauskas, K. Suhling, M. K. Kuimova, R. Vilar, Nat. Commun., 2015, 6, 8178.

33 L.-Y. Liu, W. Liu, K.-N. Wang, B.-C. Zhu, X.-Y. Xia, L.-N. Ji, Z.-W. Mao, Angew. Chemie Int. Ed., 2020, 59, 9719-9726.

34 A. Shivalingam, A. Vyšniauskas, T. Albrecht, A. J. P. White, M. K. Kuimova, R. Vilar, Chemistry, 2016, 22, 4129-4139.

35 A. Kotar, B. Wang, A. Shivalingam, J. Gonzalez-Garcia, R. Vilar, J. Plavec, Angew. Chemie - Int. Ed., 2016, 12508-12511.

36 B. W. Laursen, F. C. Krebs, Chem. Eur. J., 2001, 7, 1773-1783.

37 M. Rosenberg, K. R. Rostgaard, Z. Liao, A. Madsen, K. L. Martinez, T. Vosch, B. W. Laursen, Chem. Sci., 2018, 9, 3122-3130. 
M. Rosenberg, M. Santella, S. A. Bogh, A. V. Muñoz, H. O. B. Andersen, O. Hammerich, I. Bora, K. Lincke, B. W. Laursen, J. Org. Chem., 2019, 84, 2556-2567.

39 J. Bosson, J. Gouin, J. Lacour, Chem. Soc. Rev., 2014, 43, 2824-2840.

40 M. Rosenberg, A. K. R. Junker, T. J. Sørensen, B. W. Laursen, ChemPhotoChem, 2019, 3, 233-242.

41 F. Nüesch, M. Grätzel, Chem. Phys., 1995, 193, 1-17.

42 U. Rösch, S. Yao, R. Wortmann, F. Würthner, Angew. Chemie - Int. Ed., 2006, 45, 7026-7030.

43 T. Mahmood, Y. Wu, D. Loriot, M. Kuimova, S. Ladame, Chem. Eur. J., 2012, 18, $12349-12356$.

44 A. Rödle, M. Lambov, C. Mück-Lichtenfeld, V. Stepanenko, G. Fernández, Polymer (Guildf)., 2017, 128, 317-324.

45 S. Dileesh, K. R. Gopidas, J. Photochem. Photobiol. A Chem., 2004, 162, 115-120.

46 D. Rehm, A. Weller, Isr. J. Chem., 1970, 8, 259-271.

47 J. P. Barham, M. P. John, J. A. Murphy, J. Am. Chem. Soc., 2016, 138, 15482-15487.

48 A. Ambrus, D. Chen, J. Dai, R. A. Jones, D. Yang, Biochemistry, 2005, 44, 2048-2058.

49 K. N. Luu, A. T. Phan, V. Kuryavyi, L. Lacroix, D. J. Patel, J. Am. Chem. Soc., 2006, 128, 9963-9970.

50 A. Membrino, S. Cogoi, E. B. Pedersen, L. E. Xodo, PLoS One, 2011, 6, e24421.

51 F. Liao, H. Xu, N. Torrey, P. Road, L. Jolla, J. Am. Chem. Soc., 2007, 129, 4386-4392. 
52 G. N. Parkinson, M. P. H. Lee, S. Neidle, Nature, 2002, 417, 876-880.

53 H. Tsukube et al., in Comprehensive Supramolecular Chemistry, Pergamon, Oxford, 1996.

54 P. Thordarson, Chem. Soc. Rev., 2011, 40, 1305-1323.

55 A. Vyšniauskas, D. Ding, M. Qurashi, I. Boczarow, M. Balaz, H. L. Anderson, M. K. Kuimova, Chem. Eur. J., 2017, 11001-11010. 